Article

\title{
Synthesis, Bioevaluation and Molecular Dynamic Simulation Studies of Dexibuprofen-Antioxidant Mutual Prodrugs
}

\author{
Zaman Ashraf ${ }^{1}$, Alamgeer ${ }^{2}$, Raqiqatur Rasool ${ }^{1}$, Mubashir Hassan ${ }^{3}$, Haseeb Ahsan ${ }^{2}$, \\ Samina Afzal ${ }^{4}$, Khurram Afzal ${ }^{4}$, Hongsik Cho ${ }^{5,6}$ and Song Ja Kim ${ }^{3, *}$ \\ 1 Department of Chemistry, Allama Iqbal Open University, Islamabad 44000, Pakistan; \\ mzchem@yahoo.com (Z.A.); raqiqa_chem@yahoo.com (R.R.) \\ 2 Department of Pharmacology, Faculty of Pharmacy University of Sargodha, Sargodha 40100, Pakistan; \\ alam_yuchi@yahoo.com (A.); haseebahsan110@yahoo.com (H.A.) \\ 3 Department of Biology, College of Natural Sciences, Kongju National University, Gongju 314701, Korea; \\ mubashirhassan_gcul@yahoo.com \\ 4 Faculty of Pharmacy, BahauddinZakria University, Multan 60800, Pakistan; \\ samina.afzal@bzu.edu.pk (S.A.); khurram.afzal@bzu.edu.pk (K.A.) \\ 5 Department of Orthopaedic Surgery \& Biomedical Engineering, University of Tennessee Health Science \\ Center-Campbell Clinic, Memphis, TN 38104, USA; hcho4@uthsc.edu \\ 6 Research 151, Veterans Affairs Medical Center, Memphis, TN 38104, USA \\ * Correspondence: ksj85@kongju.ac.kr; Tel.: +82-41-850-8507
}

Academic Editors: Ge Zhang and Aiping Lu

Received: 1 November 2016; Accepted: 14 December 2016; Published: 21 December 2016

\begin{abstract}
Dexibuprofen-antioxidant conjugates were synthesized with the aim to reduce its gastrointestinal effects. The esters analogs of dexibuprofen $5 \mathrm{a}-\mathbf{c}$ were obtained by reacting its $-\mathrm{COOH}$ group with chloroacetyl derivatives $3 \mathbf{a}-\mathbf{c}$. The in vitro hydrolysis data confirmed that synthesized prodrugs $5 \mathbf{a}-\mathbf{c}$ were stable in stomach while undergo significant hydrolysis in $80 \%$ human plasma and thus release free dexibuprofen. The minimum reversion was observed at $\mathrm{pH} 1.2$ suggesting that prodrugs are less irritating to stomach than dexibuprofen. The anti-inflammatory activity of $\mathbf{5 c}$ $(p<0.001)$ is more significant than the parent dexibuprofen. The prodrug $\mathbf{5 c}$ produced maximum inhibition (42.06\%) of paw-edema against egg-albumin induced inflammation in mice. Anti-pyretic effects in mice indicated that prodrugs $\mathbf{5} \mathbf{a}$ and $\mathbf{5} \mathbf{b}$ showed significant inhibition of pyrexia $(p<0.001)$. The analgesic activity of $\mathbf{5 a}$ is more pronounced compared to other synthesized prodrugs. The mean percent inhibition indicated that the prodrug $\mathbf{5 a}$ was more active in decreasing the number of writhes induced by acetic acid than standard dexibuprofen. The ulcerogenic activity results assured that synthesized prodrugs produce less gastrointestinal adverse effects than dexibuprofen. The ex vivo antiplatelet aggregation activity results also confirmed that synthesized prodrugs are less irritant to gastrointestinal mucosa than the parent dexibuprofen. Molecular docking analysis showed that the prodrugs $5 \mathbf{a}-\mathbf{c}$ interacts with the residues present in active binding sites of target protein. The stability of drug-target complexes is verified by molecular dynamic simulation study. It exhibited that synthesized prodrugs formed stable complexes with the COX-2 protein thus support our wet lab results. It is therefore concluded that the synthesized prodrugs have promising pharmacological activities with reduced gastrointestinal adverse effects than the parent drug.
\end{abstract}

Keywords: nonsteroidal anti-inflammatory drugs (NSAIDs); mutual prodrugs; dexibuprofen; antioxidants; in vitro hydrolysis; pharmacological activity; molecular dynamics simulation 


\section{Introduction}

Ibuprofen, (R,S-2-(4-isobutylphenyl)-propionic acid) a non-steroidal anti-inflammatory drug exists in two enantiomeric forms which are present in the racemate [1]. Dexibuprofen, $S-(+)$-ibuprofen is pharmacologically more active than racemic ibuprofen which has equal quantities of $R-(-)$ and $S-(+)$ enantiomers [2]. In the dose ratio of 1:0.5 (Racemic ibuprofen vs. dexibuprofen), at least equivalent efficacy was proven in acute mild to severe somatic and visceral pain models. The physico-chemical properties of dexibuprofen are also different than the racemic ibuprofen. Dexibuprofen has a slower dissolution rate in the simulated gastric and enteric juices compared with the racemic ibuprofen [3]. Dexibuprofen possesses comparable pharmacological efficacy and tolerability to that of diclofenac, naproxen and celecoxib [4].

The most commonly encountered adverse effects of nonsteroidal anti-inflammatory drugs (NSAIDs) including dexibuprofen are stomach ulceration, bleeding, perforation and gastrointestinal (GI) irritations $[5,6]$. The free carboxylic acid group $(-\mathrm{COOH})$ present in dexibuprofen is responsible for the GI side effects $[7,8]$. Previously, a number of prodrugs of ibuprofen have been designed to temporarily mask the free carboxylic acid group to overcome gastrointestinal irritation [9-11] but so far no single NSAIDs available in market without gastrointestinal adverse effects. Esters and amides functionalities have been frequently employed for the preparation of prodrugs because they can easily be cleaved in to active drug by enzymatic hydrolysis [12,13]. Mutual prodrug consists of two pharmacologically active agents coupled together in such a way to get synergistic action.

A number of prodrugs of ibuprofen have been reported [14-16] but very few mutual prodrugs of dexibuprofen were reported $[17,18]$. The current study was undertaken to synthesize novel mutual prodrugs of dexibuprofen to reduce its gastrointestinal effects while maintaining the pharmacological profile. The carboxylic group of dexiboprofen was temporarily masked by synthesizing its ester analogs with naturally occurring phenolic antioxidants sesamol and umbelliferon as well as alcoholic compound menthol. The selected promoieties have traditional medicinal uses and flavoring properties with well-documented safety profiles [19]. The in vitro hydrolysis of the synthesized mutual prodrugs $(\mathbf{5 a}-\mathbf{c})$ was carried out in aqueous buffers and in $80 \%$ human plasma pH 7.4 for ensuring their stability. Pharmacological screenings like anti-inflammatory, analgesic, antipyretic and ulcerogenic activities of these prodrugs were evaluated and results were compared with standard dexibuprofen. The ex vivo platelet aggregation activity of the synthesized prodrugs was also carried out. Molecular docking and simulation studies were performed to predict the binding affinity of synthesized prodrugs with COX-2.

\section{Result and Discussion}

\subsection{Synthesis of Prodrugs}

The mutual prodrugs synthesis is beneficial as it minimizes the undesirable effects of a drug along with increase the pharmacological response. Dexibuprofen-antioxidants mutual prodrugs have been synthesized by following the previously reported method with slight modification [20]. For the first time natural antioxidants menthol, sesamol and umbelliferon were used for the preparation of mutual prodrugs of dexibuprofen. Chloroacetyl chloride was condensed with these natural antioxidants $\mathbf{2 a - c}$ to afford their chloroacetyl chloride derivatives 3a-c. Dexibuprofen was then reacted with derivatives $3 \mathbf{a}-\mathbf{c}$ to afford mutual prodrugs $\mathbf{5 a - c}$ (Scheme 1). The structures of the synthesized prodrugs were confirmed by FTIR, ${ }^{1} \mathrm{H}-\mathrm{NMR},{ }^{13} \mathrm{C}-\mathrm{NMR}$ and Mass spectral data. The FTIR spectral data showed the characteristic absorption for $\mathrm{C}=\mathrm{O}$ at $1730-1718 \mathrm{~cm}^{-1}$ with disappearance of $-\mathrm{OH}$ for carboxylic group which confirmed the formation of ester prodrugs. 


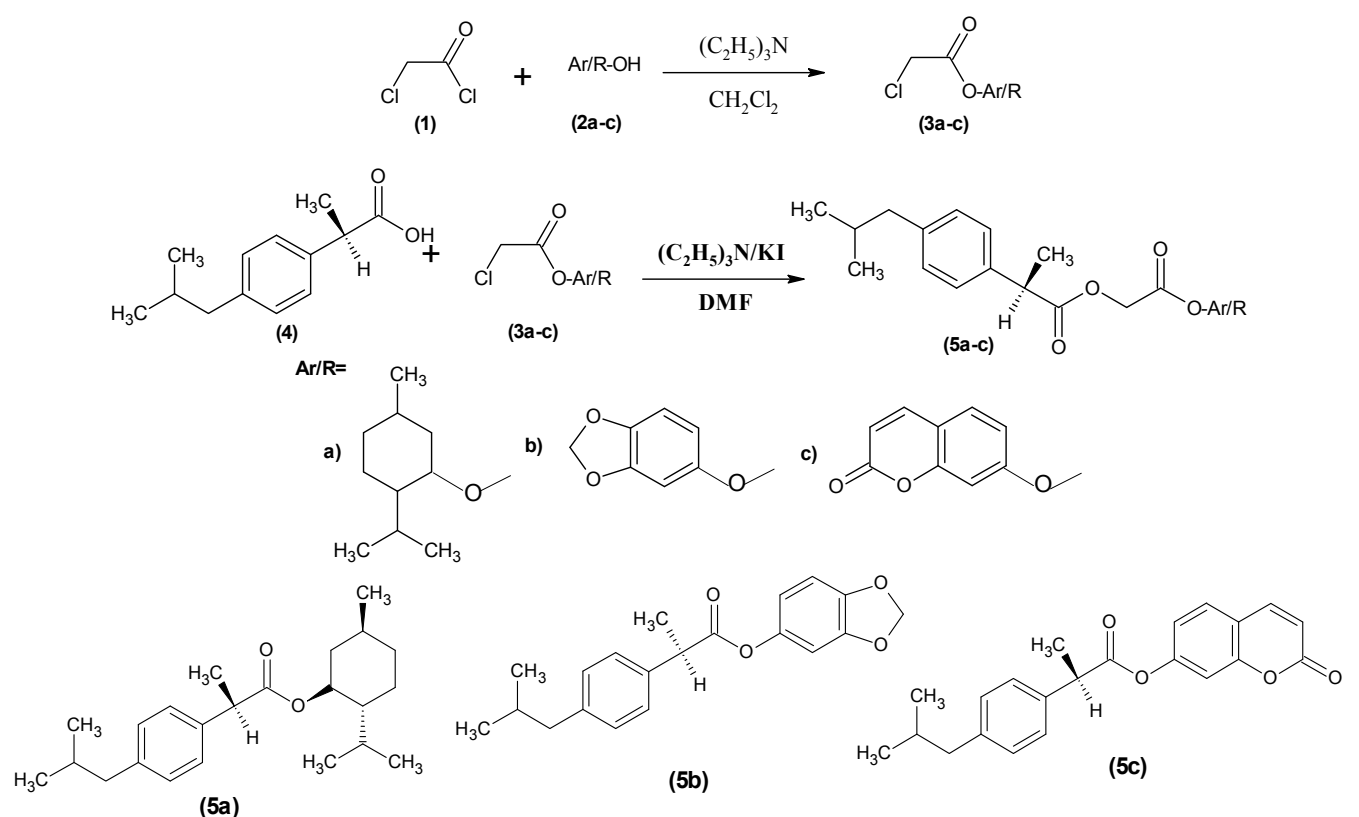

Scheme 1. Synthesis and chemical structures of dexibuprofen-antioxidant mutual prodrugs (5a-c).

\subsection{Hydrolysis Studies of Mutual Prodrugs Dexibuprofen}

The in vitrohydrolysis of the synthesized prodrugs to free dexibuprofen was performed at $\mathrm{pH} 1.2$ and 7.4 to mimic the stomach and intestinal environment respectively. The release of free drug by hydrolysis of the prodrugs was also studied in $80 \%$ human plasma at $\mathrm{pH} 7.4$ to mimic the $\mathrm{pH}$ of blood. The prodrugs at gastric $\mathrm{pH}$ (SGF, $\mathrm{pH}$ 1.2) are not hydrolyzed to free dexibuprofen while at higher (SIF pH 7.4) hydrolysis of the prodrugs is higher resulting in increase the amount free dexibuprofen. The dexibuprofen produced on hydrolysis after $1 \mathrm{~h}$ (in SIF, $\mathrm{pH} 7.4$ ) of prodrugs $5 \mathrm{a}-\mathrm{c}$ was found from $6.34 \%$ to $18.02 \%$. The amount of dexibuprofen regenerated on hydrolysis after $1 \mathrm{~h}$ (in $80 \%$ human plasma, pH 7.4) was found to be $69.4 \%, 61.5 \%$ and $64.7 \%$ in prodrugs $5 \mathbf{a}-\mathbf{c}$, respectively. All of the mutual prodrugs showed very encouraging hydrolysis rate in $80 \%$ human plasma ( $\mathrm{pH} 7.4)$ and the regeneration of active drug was found to be $61 \%$ to $92 \%$. The In vitro hydrolytic patterns of the ester prodrugs $\mathbf{5 a - c}$ in SIF ( $\mathrm{pH} 7.4$ ) and in $80 \%$ human plasma ( $\mathrm{pH} 7.4$ ) are presented in Figures 1 and 2 , respectively.

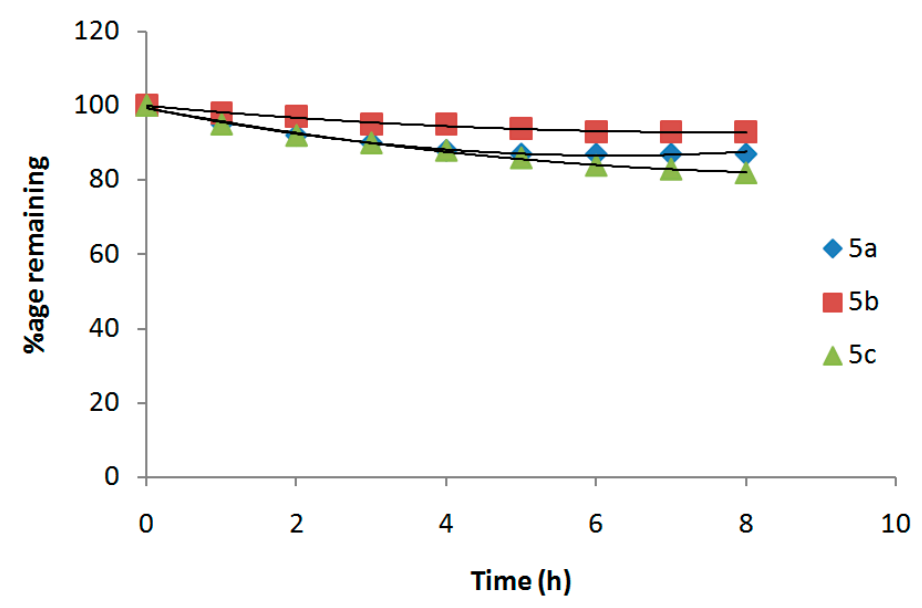

Figure 1. In vitro hydrolytic pattern of the ester prodrugs $(\mathbf{5 a}-\mathbf{c})$ in simulated intestinal fluid (SIF) (pH 7.4). 


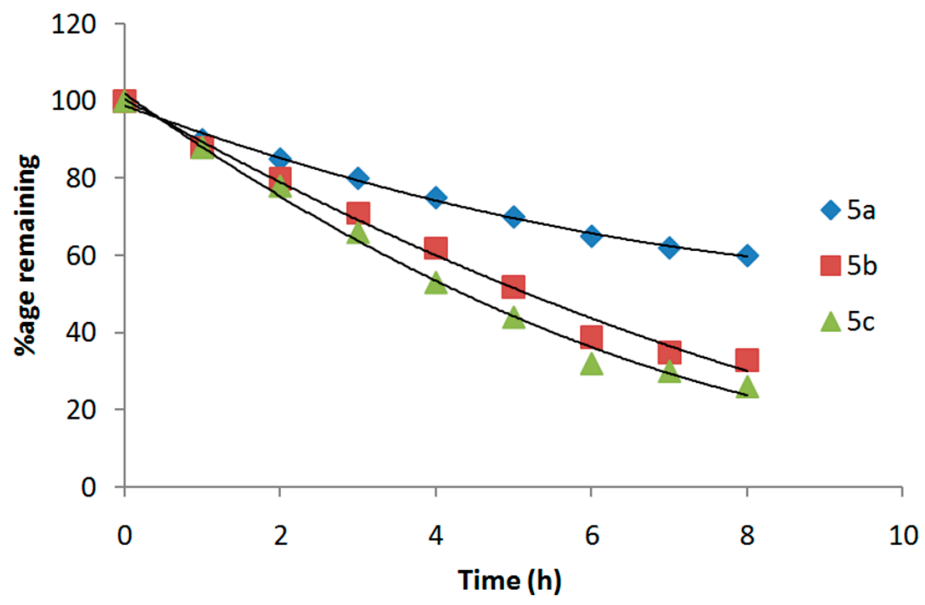

Figure 2. In vitro hydrolytic pattern of the ester prodrugs $(\mathbf{5 a}-\mathbf{c})$ in $80 \%$ human plasma ( $\mathrm{pH} 7.4)$.

\subsection{Pharmacology}

Anti-Inflammatory Activity

Anti-inflammatory activity results confirmed that there was a gradual increase in paw volume of mice in the control group. However, in the treated groups, all prodrugs $\mathbf{5 a - c}$ produced a significant reduction in edema formation. The prodrug $5 c$ exhibited anti-inflammatory effects by significantly $(p<0.001)$ inhibiting the paw-edema at $4 \mathrm{~h}$ of post carrageenan induced inflammation with percentage inhibition of $(28.99 \%)$. However, prodrugs $\mathbf{5 a}$ and $\mathbf{5 b}$ produced comparatively less anti-inflammatory response $(p<0.01)$ than standard dexibuprofen (Tables 1 and 2). Carrageenan induce edema in bi-phase, the duration of first phase is $0-2.5 \mathrm{~h}$ post injection of agent. During this phase, different inflammatory mediators such as histamine, serotonin and bradykinin are released that cause vasodilation [21], whereas during the second phase inflammatory mediators such as prostaglandins are released. The experimental results showed that all synthetic prodrugs exhibited very significant inhibitory effect $(p<0.001)$ in second phase of induction of edema. Thus, this effect could be due to inhibitory effect on cyclooxygenase enzyme that leads to decreased production of Prostaglandins. The anti-inflammatory effect of standard dexibuprofen is also due to inhibition of both COX-1 and COX-2 [22].

Table 1. Effect of mutual prodrugs $(5 \mathbf{a}-\mathbf{c})$ in carrageenan induced edema $(\mathrm{mm})$ in mice.

\begin{tabular}{|c|c|c|c|c|c|}
\hline Serial. No. & $\begin{array}{l}\text { Inflammation } \\
\text { at } 0 \mathrm{~h}(\mathrm{~mm})\end{array}$ & $\begin{array}{l}\text { Inflammation } \\
\text { at } 1 \mathrm{~h}(\mathrm{~mm})\end{array}$ & $\begin{array}{l}\text { Inflammation } \\
\text { at } 2 \mathrm{~h}(\mathrm{~mm})\end{array}$ & $\begin{array}{l}\text { Inflammation } \\
\text { at } 3 \mathrm{~h}(\mathrm{~mm})\end{array}$ & $\begin{array}{c}\text { Inflammation } \\
\text { at } 4 \mathrm{~h}(\mathrm{~mm})\end{array}$ \\
\hline Dose & Mean \pm SEM & Mean \pm SEM & Mean \pm SEM & Mean \pm SEM & Mean \pm SEM \\
\hline Control $10 \mathrm{mg} / \mathrm{kg}$ & $4.17 \pm 0.08$ & $4.40 \pm 0.10$ & $4.6 \pm 0.06$ & $4.85 \pm 0.06$ & $5.07 \pm 0.06$ \\
\hline Dexibuprofen $20 \mathrm{mg} / \mathrm{kg}$ & $4.37 \pm 0.06$ & $\begin{array}{c}4.35 \pm 0.06^{\mathrm{ns}} \\
(1.1 \%)\end{array}$ & $\begin{array}{l}4.07 \pm 0.02 * * * \\
\quad(11.71 \%)\end{array}$ & $\begin{array}{c}3.90 \pm 0.04^{* * * *} \\
(19.58 \%)\end{array}$ & $\begin{array}{c}3.75 \pm 0.06^{* * * *} \\
(26.03 \%)\end{array}$ \\
\hline 5 a $20 \mathrm{mg} / \mathrm{kg}$ & $4.42 \pm 0.05$ & $\begin{array}{c}4.50 \pm 0.04^{\mathrm{ns}} \\
(-2.27 \%)\end{array}$ & $\begin{array}{c}4.25 \pm 0.06 * * \\
(7.80 \%)\end{array}$ & $\begin{array}{l}4.12 \pm 0.06^{* * *} \\
\quad(15.05 \%)\end{array}$ & $\begin{array}{c}3.92 \pm 0.02 \text { *** } \\
(22.68 \%)\end{array}$ \\
\hline $5 \mathbf{b} 20 \mathrm{mg} / \mathrm{kg}$ & $4.37 \pm 0.04$ & $\begin{array}{c}4.22 \pm 0.1^{\mathrm{ns}} \\
(4.09 \%)\end{array}$ & $\begin{array}{c}4.25 \pm 0.06^{* *} \\
(7.80 \%)\end{array}$ & $\begin{array}{c}4.15 \pm 0.02 * * * \\
\quad(14.43 \%)\end{array}$ & $\begin{array}{c}3.92 \pm 0.05 \\
\quad(22.68 \%)\end{array}$ \\
\hline $5 \mathrm{c} 20 \mathrm{mg} / \mathrm{kg}$ & $4.32 \pm 0.04$ & $\begin{array}{c}4.22 \pm 0.04^{\mathrm{ns}} \\
\quad(4.09 \%)\end{array}$ & $\begin{array}{c}4.05 \pm 0.02 * * * \\
(12.14 \%)\end{array}$ & $\begin{array}{c}3.80 \pm 0.04 * * * \\
(21.64 \%)\end{array}$ & $\begin{array}{c}3.60 \pm 0.04 \text { *** } \\
(28.99 \%)\end{array}$ \\
\hline
\end{tabular}

Results are expressed as means \pm SEM. Significant at, ${ }^{* *}=p<0.01,{ }^{* * *}=p<0.001,{ }^{\text {ns }}=$ non-significant when compared to control. Values in bracket indicate percent inhibition. 
Table 2. Effect of mutual prodrugs $(5 \mathbf{a}-\mathbf{c})$ in egg albumin induced paw edema $(\mathrm{mm})$ in mice.

\begin{tabular}{|c|c|c|c|c|}
\hline Treatment/Dose & $\begin{array}{c}\text { Inflammation } \\
\text { at } 0 \mathrm{~h}(\mathrm{~mm})\end{array}$ & $\begin{array}{l}\text { Inflammation } \\
\text { at } 1 \mathrm{~h}(\mathrm{~mm})\end{array}$ & $\begin{array}{l}\text { Inflammation } \\
\text { at } 2 \mathrm{~h}(\mathrm{~mm})\end{array}$ & $\begin{array}{l}\text { Inflammation } \\
\text { at } 3 \mathrm{~h}(\mathrm{~mm})\end{array}$ \\
\hline Dose & Mean \pm SEM & Mean \pm SEM & Mean \pm SEM & Mean \pm SEM \\
\hline Control $10 \mathrm{~mL} / \mathrm{kg}$ & $4.35 \pm 0.05$ & $4.40 \pm 0.10$ & $4.80 \pm 0.10$ & $5.22 \pm 0.07$ \\
\hline Dexibuprofen $20 \mathrm{mg} / \mathrm{kg}$ & $4.05 \pm 0.41$ & $\begin{array}{c}3.20 \pm 0.04^{* * *} \\
(27.27 \%)\end{array}$ & $\begin{array}{c}3.42 \pm 0.20 \text { *** } \\
(28.75 \%)\end{array}$ & $\begin{array}{c}3.00 \pm 0.00 * * * \\
(42.52 \%)\end{array}$ \\
\hline $5 \mathbf{a} 20 \mathrm{mg} / \mathrm{kg}$ & $4.67 \pm 0.08$ & $\begin{array}{c}3.70 \pm 0.16^{*} \\
(15.90 \%)\end{array}$ & $\begin{array}{c}3.37 \pm 0.20^{* * * *} \\
(29.79 \%)\end{array}$ & $\begin{array}{c}3.30 \pm 0.04^{* * * *} \\
(36.78 \%)\end{array}$ \\
\hline $5 \mathbf{b ~} 20 \mathrm{mg} / \mathrm{kg}$ & $4.15 \pm 0.32$ & $\begin{array}{c}3.95 \pm 0.02 \mathrm{~ns} \\
(10.22 \%)\end{array}$ & $\begin{array}{c}3.40 \pm 0.20 * * * \\
(29.16 \%)\end{array}$ & $\begin{array}{c}3.17 \pm 0.11^{* * * *} \\
(39.27 \%)\end{array}$ \\
\hline $5 \mathrm{c} 20 \mathrm{mg} / \mathrm{kg}$ & $4.60 \pm 0.33$ & $\begin{array}{c}3.12 \pm 0.06^{* * *} \\
(29.09 \%)\end{array}$ & $\begin{array}{c}3.02 \pm 0.06^{* * *} \\
(37.08 \%)\end{array}$ & $\begin{array}{l}2.92 \pm 0.07^{* * * *} \\
\quad(44.06 \%)\end{array}$ \\
\hline
\end{tabular}

Results are expressed as means \pm SEM. Significant at ${ }^{*}=p<0.01,{ }^{* * *}=p<0.001{ }^{\text {ns }}=$ non-significant when compared to control. Values in bracket indicate percent inhibition.

Prodrugs 5a-c in egg induced inflammation also showed significant $(p<0.001)$ anti-inflammatory effects at $3 \mathrm{~h}$ post albumin induced inflammation with maximum inhibition (42.06\%) produced by 5c. The standard drug dexibuprofen also produced significant $(p<0.001)$ anti-inflammatory effects at $3 \mathrm{~h}$ after the administration of egg albumin. Anti-inflammatory effects exhibited by prodrugs were comparable to parent dexibuprofen. Previously, it has been reported that injection of egg albumin caused release of histamine and 5-HT which lead to inflammation. Histamine is a vasodilator and causes increase in vascular permeability $[23,24]$. The anti-inflammatory effects of synthesized prodrugs might be due to inhibiting the release of mediators such as histamine which cause swellings associated with inflammation [25].

\subsection{Analgesic Activity}

Dexibuprofen mutual prodrugs $5 \mathbf{a}-\mathbf{c}$ exhibited a significant $(p<0.001)$ reduction in writhings induced by acetic acid. The mean percent inhibition indicated that the prodrug $5 \mathbf{a}$ was more active in decreasing the number of writhes induced by acetic acid than standard dexibuprofen. On the other hand, $\mathbf{5 b}$ and $\mathbf{5 c}$ showed comparable analgesic activity to dexibuprofen. On the contrary, all prodrugs displayed higher analgesic activity than standard dexibuprofen in formalin induced licking in mice. The analgesic response of synthetic prodrugs in formalin induced licking in mice was in order of $5 \mathbf{a}>5 \mathbf{b}>\mathbf{5 c}$ (Table 3$)$.

Table 3. Effect of prodrugs $(\mathbf{5 a}-\mathbf{c})$ against acetic acid induced writhing and formalin induced licking in mice.

\begin{tabular}{ccc}
\hline Treatment/Dose & No. of Writhing & Lickings Time \\
\hline Dose & Mean \pm SEM & Mean \pm SEM \\
\hline Control $10 \mathrm{~mL} / \mathrm{kg}$ & $37.20 \pm 1.10$ & $2.83 \pm 0.26$ \\
\hline Dexibuprofen $20 \mathrm{mg} / \mathrm{kg}$ & $17.06 \pm 1.08^{* * *}(54.12 \%)$ & $1.60 \pm 0.22^{* * *}(43.46 \%)$ \\
\hline $\mathbf{5 a} 20 \mathrm{mg} / \mathrm{kg}$ & $15.00 \pm 1.29^{* * *}(59.67 \%)$ & $0.70 \pm 0.22^{* * *}(75.26 \%)$ \\
\hline $\mathbf{5 b} 20 \mathrm{mg} / \mathrm{kg}$ & $17.50 \pm 0.64^{* * *}(52.95 \%)$ & $0.98 \pm 0.17^{* * *}(65.37 \%)$ \\
\hline $\mathbf{5 c} 20 \mathrm{mg} / \mathrm{kg}$ & $18.25 \pm 0.85^{* * *}(50.94 \%)$ & $1.31 \pm 0.07^{* * *}(53.71 \%)$ \\
\hline
\end{tabular}

Results are expressed as means \pm SEM. Significant at ${ }^{* *}=p<0.001$ when compared to control. The figure in brackets represents percentage inhibition. 
In acetic acid induced writhing model, abdominal constriction response is due to peritoneal receptors [26]. It is reported that level of prostaglandin E2 (PGE2) and PGF2 in peritoneal fluids has been increased [27] as well as lipoxygenase products [28] when acetic acid is administered to induce writhing. The analgesic activity of prodrugs might be due to inhibition of synthesis and release of PGs and other endogenous substances as already proposed. Likewise, formalin produces response in two phases; the first phase is due to stimulation of nociceptors while second phase is of inflammatory pain origin [29]. The mutual prodrugs at a dose of $20 \mathrm{mg} / \mathrm{kg}$ significantly $(p<0.001)$ reduced licking time in mice. The analgesic activity of prodrugs $5 \mathbf{a}-\mathbf{c}$ was evaluated on the first and second phase of formalin-induced paw licking test. The results verified that these analgesic effects may be due to its central action as proposed previously by Ghannadi et al., 2005 [30].

\subsection{Antipyretic Activity}

Anti-pyretic effects in mice indicated that prodrugs $\mathbf{5 a}$ and $\mathbf{5 b}$ showed significant inhibition of pyrexia $(p<0.001)$. Prodrug $5 \mathrm{c}$ showed significant inhibition of pyrexia after $2 \mathrm{~h}$ induction of pyrexia while standard dexibuprofen showed less significant $(p<0.05)$ inhibition of pyrexia. It has been well established that yeast induces pyrexia by increasing the production of prostaglandins ( $\left.\mathrm{PGE}_{2}\right)$, which raises the set point of thermoregulatory center in hypothalamus [31]. Therefore, it is proposed that $\mathbf{5 b}$ may likely to reduce pyrexia by decreasing prostaglandin E2 concentration in brain particularly in the hypothalamus [32] or by increasing the production of the body's own antipyretic substances such as vasopressin and arginine [33]. Antipyretic effects of dexibuprofen may be due to the action on the hypothalamus, resulting in an increased peripheral blood flow, vasodilation and subsequent heat dissipation. Table 4 depicts the antipyretic activity results of the synthesized mutual prodrugs $5 \mathbf{a}-\mathbf{c}$.

Table 4. Effect of prodrugs $(5 \mathrm{a}-\mathrm{c})$ against yeast induced pyrexia $\left({ }^{\circ} \mathrm{F}\right)$ in mice.

\begin{tabular}{cccccc}
\hline Treatment/Dose & $\begin{array}{c}\text { Temperature } \\
\text { before } \\
\text { Induction }\left({ }^{\circ} \mathbf{F}\right)\end{array}$ & $\begin{array}{c}\text { After } \mathbf{2 4} \mathbf{h} \text { of } \\
\text { Induction }\left({ }^{\circ} \mathbf{F}\right)\end{array}$ & $\mathbf{1 ~ h ~}\left({ }^{\circ} \mathbf{F}\right)$ & $\mathbf{2} \mathbf{~ h ~}\left({ }^{\circ} \mathbf{F}\right)$ & $\mathbf{3 ~ h}\left({ }^{\circ} \mathbf{F}\right)$ \\
\hline $\begin{array}{c}\text { Dose } \\
\text { Control }\end{array}$ & Mean \pm SEM & Mean \pm SEM & Mean \pm SEM & Mean \pm SEM & Mean \pm SEM \\
$(10 \mathrm{~mL} / \mathrm{kg})$ & $95.17 \pm 0.34$ & $96.02 \pm 0.44$ & $96.25 \pm 0.39$ & $96.22 \pm 0.39$ & $96.22 \pm 0.39$ \\
$\begin{array}{c}\text { Dexibuprofen } \\
(20 \mathrm{mg} / \mathrm{kg})\end{array}$ & $95.20 \pm 0.21$ & $95.77 \pm 0.26$ & $95.25 \pm 0.37^{\mathrm{ns}}$ & $95.02 \pm 0.35^{*}$ & $94.97 \pm 0.31^{*}$ \\
$\mathbf{5 a}(20 \mathrm{mg} / \mathrm{kg})$ & $94.37 \pm 0.04$ & $95.14 \pm 0.02$ & $94.97 \pm 0.06^{*}$ & $94.62 \pm 0.08^{* *}$ & $94.37 \pm 0.08^{* * *}$ \\
$\mathbf{5 b}(20 \mathrm{mg} / \mathrm{kg})$ & $94.25 \pm 0.10$ & $95.47 \pm 0.19$ & $94.87 \pm 0.06^{* *}$ & $94.5 \pm 0.12^{* * *}$ & $94.17 \pm 0.06^{* * *}$ \\
$\mathbf{5 c}(20 \mathrm{mg} / \mathrm{kg})$ & $98.95 \pm 0.04$ & $102.1 \pm 0.96$ & $98.35 \pm 0.05^{* * *}$ & $97.65 \pm 0.15^{* *}$ & $97.25 \pm 0.08^{\mathrm{ns}}$ \\
\hline
\end{tabular}

Results are expressed as means \pm SEM. Significant at ${ }^{*}=p<0.05,{ }^{* *}=p<0.01,{ }^{* * *}=p<0.001,{ }^{\text {ns }}=$ non-significant when compared to control.

\subsection{Ulcerogenic Activity}

To find adverse effects on gastrointestinal mucosa the ulcerogenic activity of the synthesized dexibuprofen-antioxidant mutual prodrugs $\mathbf{5 a - c}$ was performed. The ulcer index (UI) of animals administered with dexibuprofen prodrugs $\mathbf{5 a - c}$ were compared with that of dexibuprofen and results were evaluated using one way ANOVA (followed by Tukey) test (Table 5). Ulcer index shown by dexibuprofen treated animals is 2.89 and is due to direct contact mechanism as well as prostaglandin inhibition. All of the synthesized dexibuprofen-antioxidant mutual prodrugs $\mathbf{5 a - c}$ significantly reduce the gastrotxicity of dexibuprofen as the ulcer index produced by synthesized prodrugs is less than parent dexibuprofen. The present study did not include the side effects associated with the long term use of the prodrugs. 
Table 5. Ulcerogenic activity of synthesized mutual prodrugs (5a-c) and Dexibuprofen.

\begin{tabular}{ccc}
\hline Serial. No. & Compounds & Ulcer Index (Mean \pm SEM) \\
\hline Control group & CMC & $0.37 \pm 0.37$ \\
1 & Dexibuprofen & $2.89 \pm 0.63$ \\
2 & $\mathbf{5 a}$ & $1.55 \pm 0.09^{* *}$ \\
3 & $\mathbf{5 b}$ & $1.34 \pm 0.06^{* *}$ \\
4 & $\mathbf{5 c}$ & $1.61 \pm 0.58^{*}$ \\
\hline
\end{tabular}

$\mathrm{CMC}^{*}=$ Carboxymethyl cellulose, Values are expressed as Mean \pm SEM, $(n=6)$ by one way ANOVA (followed by Tukey) test, Significant at ${ }^{*}=p<0.05,{ }^{* *}=p<0.01$ vs. Dexibuprofen.

\subsection{Ex Vivo Antiplatelet Aggregation Activity}

Dexibuprofen-antioxidant mutual prodrugs $(\mathbf{5 a}-\mathbf{c})$ significantly inhibited platelet aggregation of rat platelet rich plasma induced by ADP or collagen. Figure 3 displays the inhibitory effects of synthesized prodrugs $\mathbf{5 a - c}$. All of the synthesized prodrugs $\mathbf{5 a - c}$ having higher potential to inhibit the platelet aggregation than the positive control ASA. The prodrug $\mathbf{5 c}$ exhibited most potent inhibitory effects compared to other synthesized prodrugs.

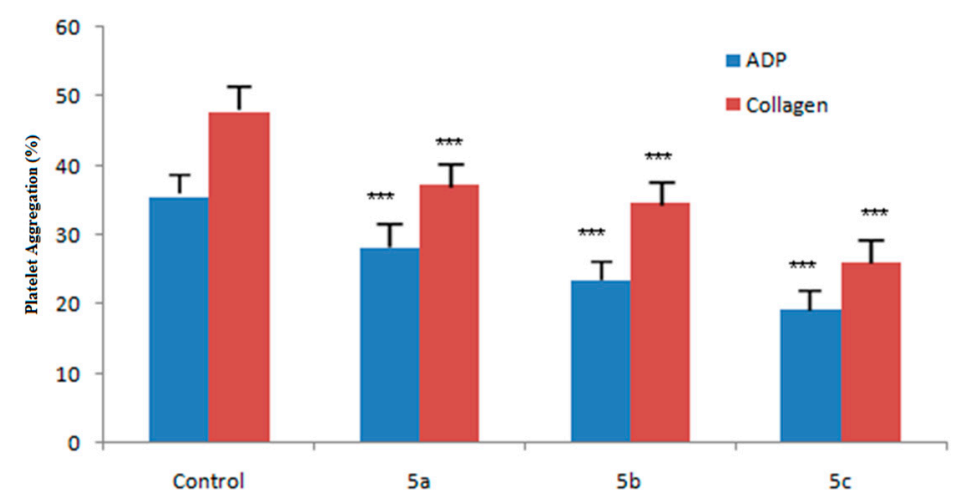

Figure 3. Antiplatelet aggregation activity of synthesized prodrugs $(\mathbf{5 a}-\mathbf{c})$ in rats administered orally. The platelet rich plasma was obtained from the blood $90 \mathrm{~min}$ after prodrugs $(100 \mathrm{mg} / \mathrm{kg})$ were orally administered into Sprague-Dawley (SD) rats, and platelet aggregation was induced by adenosinediphosphate (ADP) $(1.3 \mu \mathrm{mol} / \mathrm{L})$ or collagen $(32.8 \mu \mathrm{g} / \mathrm{mL})$, Significant at ${ }^{* * *}=p<0.001$.

\subsection{Molecular Docking Analysis}

Molecular docking of the parent dexibuprofen and synthesized prodrugs $\mathbf{5 a - c}$ against target protein have been performed. From these data, we can find the role of attached promoities in the receptor interactions. This is helpful to design new, more potent derivatives of dexibuprofen.

Cyclooxygenase-2 Evaluation

COX-2 is a multi-domain protein (A, B, C and D), comprising 552 residues. The crystal structure of COX- 2 consists of $44 \%$ helices ( 248 residues), $11 \% \beta$ sheet ( 64 residues) and $43 \%$ coil ( 240 residues). The X-ray diffraction study confirmed its resolution $2.19 \AA$, R-value 0.255 and unit cell crystal dimensions like length and angles of coordinates. The unit cell length values and angle dimensions were observed for $\mathrm{a}=180.27 \AA, \mathrm{b}=134.27 \AA$ and $\mathrm{c}=122.61 \AA$ with $\alpha, \beta$ and $\gamma$ angles $90^{\circ}, 90^{\circ}$ and $90^{\circ}$ respectively. The reliability and efficacy of cox-2 3D structure was confirmed by Ramachandran plots. The Ramachandran plots indicated that the $97.3 \%$ of all residues were present in favored regions and $100.0 \%$ residues were in allowed regions (Figure S1). 


\subsection{Prodrug Ligands Evaluation}

The prodrugs $5 \mathbf{a}-\mathbf{c}$ were analyzed computationally to predict their basic molecular and chemo-informatic properties (Table S1). Literature study established a standard value for molar refractivity (MR) (40 to $\left.130 \mathrm{~cm}^{3}\right)$, molecular weight $(160$ to $480 \mathrm{~g} / \mathrm{mol})$ and PSA $\left(<89 \AA^{2}\right)$ [34,35]. The 5a-c results showed that MR $\left(116.26,102.69\right.$ and $\left.110.04 \mathrm{~cm}^{3}\right)$ and PSA $\left(40.80,58.27\right.$, and $\left.61.56 \AA^{2}\right)$ predicted values are much effective compared to standard values. Lipinski's rule of five (RO5) evaluations also presented their good therapeutic potential of ligands. It has been studied that that poor permeation is observed in the presence of greater values $(>10,<5)$ of HBA and HBD, respectively [36]. The computational analysis showed that all prodrugs $\mathbf{5 a}-\mathbf{c}$ have $<10 \mathrm{HBA}$ and $<5 \mathrm{HBD}$ and comparable values for molecular weight $(\mathrm{g} / \mathrm{mol})$ and $\log P$ with standard values $(<500 \mathrm{~g} / \mathrm{mol}$ and $<5)$. The RO5 also rationalizes that molecules having poor absorption are the results of $>5 \mathrm{HBD},>10 \mathrm{HBA}$, MWT over 500 , and $\log P$ more than 5 . However, there are few existing drugs that violate the RO5 rule and have therapeutic potential $[37,38]$. $\mathbf{5 b}$ showed good drug likeness value (1.22) as compared to $\mathbf{5 a}(0.83)$ and (5b) (1.04). Overall, these predicted values justify the significance of $\mathbf{5 a - c}$ compounds as potential drug candidates.

\subsection{Binding Energy Analysis}

The prodrugs docked complexes of dexibuprofen and 5a-c were analyzed and evaluated on minimum energy $(\mathrm{kcal} / \mathrm{mol})$ value as mentioned in Table 6 . Among all the docked complexes the $\mathbf{5 b}$ showed lowest binding energy value $(-9.90 \mathrm{kcal} / \mathrm{mol})$ as compared to others. Moreover, $\mathbf{5 a}$ and $5 \mathbf{c}$ also possess good binding energy values $(-8.90$ and $-9.40 \mathrm{kcal} / \mathrm{mol}$, respectively). The binding energy value of the parent dexibuprofen is $-8.60 \mathrm{kcal} / \mathrm{mol}$. Based upon the docking energy values it is proposed that all of synthesized prodrugs have comparable therapeutic potential. The binding energy values of all the docked complexes are also shown in the Table S2.

Table 6. Docking results of pro-drug compounds using AutoDockVina.

\begin{tabular}{ccc}
\hline Prodrugs & Docking Energy (kcal/mol) & Binding Pocket Residues \\
\hline 5a & -8.90 & $\begin{array}{c}\text { Gln189, His193, Lys197, Leu377, Phe390, Val281, } \\
\text { Leu280, val273, Glu276, Gln275, His }\end{array}$ \\
\hline 5b & -9.90 & $\begin{array}{c}\text { Gln189, His193, Thr192, Ala188, Phe186, Tyr371, } \\
\text { Trp373, His374, Leu276, Leu377, Ala429, } \\
\text { Val430,Val433, Phe390, Leu394, Val281, Leu280 }\end{array}$ \\
\hline 5c & -9.40 & $\begin{array}{c}\text { His193, Thr192, Ala188, Phe185, Val277, Lys197, } \\
\text { Thr198, His372, Tyr371, His374, Leu377, Ala185 }\end{array}$ \\
\hline Dexibuprofen & -8.60 & Gln189, Phe390, Val281, Leu263, Leu394 and Leu377 \\
\hline
\end{tabular}

\subsection{Hydrogen Bonding Analysis}

The hydrogen bonding analyses showed that dexibuprofen and synthesized prodrugs $\mathbf{5 a - c}$ directly interact with the binding pocket residues of targeted protein. Figures 4 and 5 showed that compound $\mathbf{5 a}$ and $\mathbf{5 b}$ interact with same residues GLN189 and HIS193 in the active binding site of targeted protein. The ester carbonyl oxygen and phenoxy oxygen in $\mathbf{5 a}$ formed hydrogen bonds with GLN172 and HIS176 at a bonding distances 2.40 and $3.00 \AA$ respectively. Similarly, the ester and methylene oxygen in $\mathbf{5 b}$ interact through hydrogen bonds with same residues GLN189 and HIS193 at bonding distances 2.44 and $3.60 \AA$, respectively. The comparative analysis showed that both produgs $5 \mathbf{a}$ and $\mathbf{5 b}$ confined at the same position in the active region of target proteins. The binding energy values $(-8.90$ and $-9.90 \mathrm{kcal} / \mathrm{mol})$ and strong binding interactions assure their greater affinity to bind at active binding site of COX-2. The 5c-receptor docked complex showed the conformational state of prodrug molecule with hydrogen bonds interactions near the receptor binding pocket (Figure 6). The (5c) docking result showed that three hydrogen bonds were observed at HIS374 and HIS372 
residues position in the target protein. The coumarin lactonic oxygens forms two hydrogen bonds with HIS374 having bond length 3.64 and $3.54 \AA$ A. Similarly, the ester oxygen of same compound also forms hydrogen bond with HIS355 with bond distance $3.68 \AA$. The dexibuprofen docked complex with target protein is presented in Figure 7 which showed that the dexibuprofen and synthesized prodrugs interacts in the active binding site residues. The carboxylic oxygen in dexibuprofen interacted with TYR295 at a bonding distance of $2.90 \AA$. The literature study also showed that binding pocket residues are common in our present result, which justified the significance of ligands binding [39].

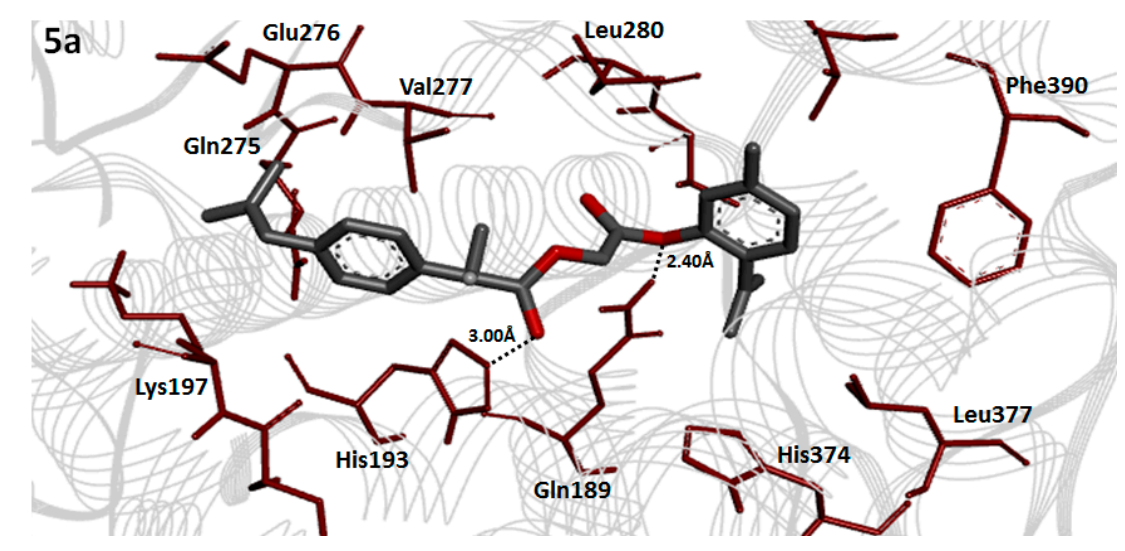

Figure 4. Docking interactions of (5a) with receptor. The COX-2 protein chain is highlighted in light grey color in wire format. The dark grey color showed the ligand structure while the embedded red colors showed oxygen moiety. The binding pocket interacted residues are highlighted in dark red color and black dotted lines justify the hydrogen bondings. Two hydrogen bonds were observed with GLN189 and HIS193 at a distance 2.40 and $3.00 \AA$, respectively.

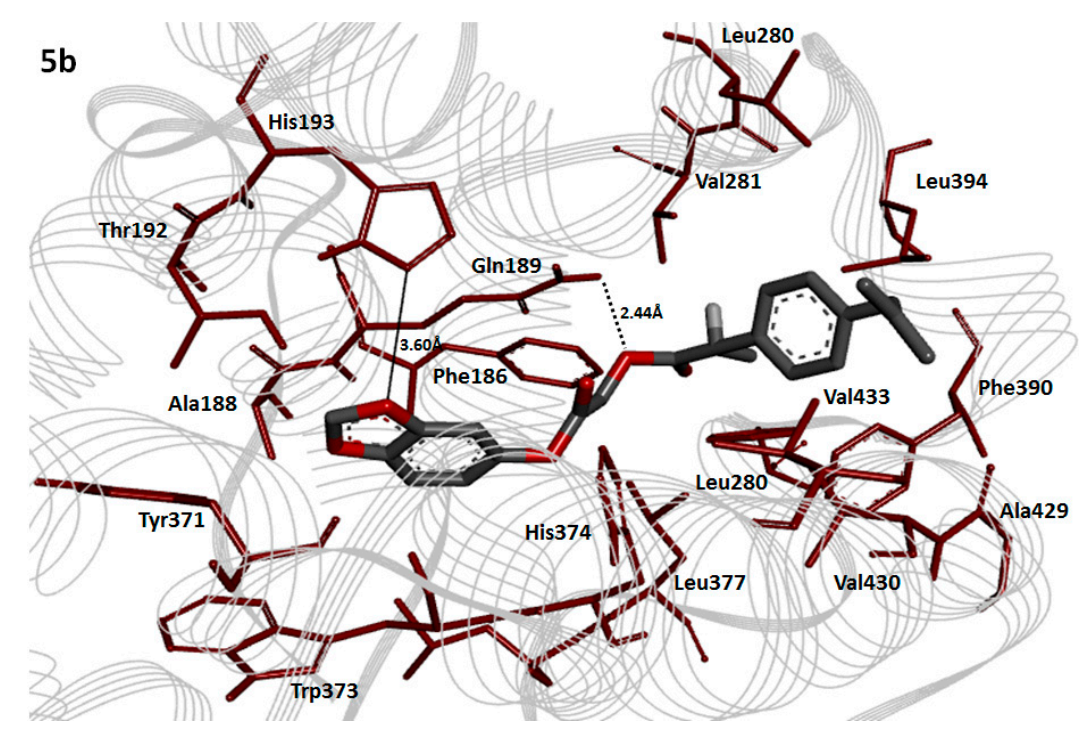

Figure 5. Docking interactions of (5b) with receptor. The COX-2 protein chain is highlighted in light grey color in wire format. The dark grey color showed the ligand structure while the embedded red colors showed oxygen moiety. The binding pocket interacted residues are highlighted in dark red color and black dotted lines justify the hydrogen bondings. Two hydrogen bonds were observed with GLN189 and HIS193 at a distance 2.44 and $3.60 \AA$, respectively. 


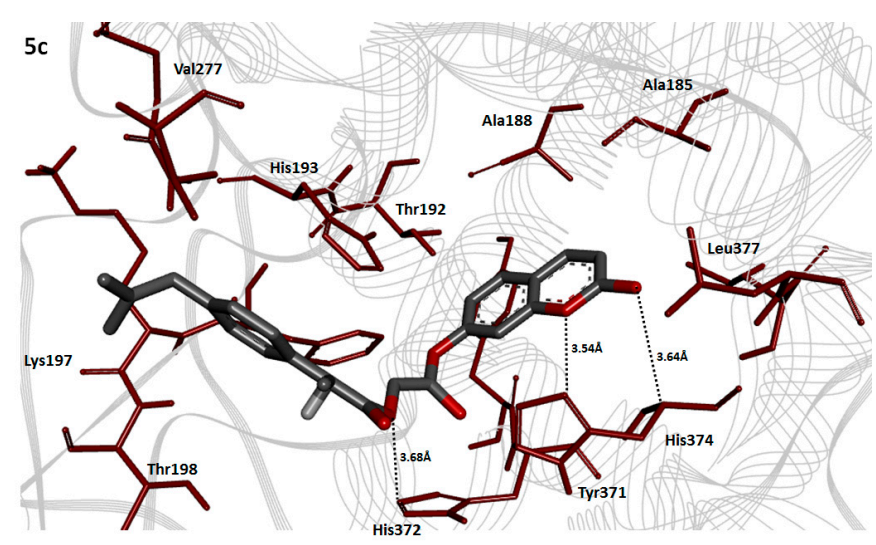

Figure 6. Docking interactions of (5c) with receptor. The COX-2 protein chain is highlighted in light grey color in wire format. The dark grey color showed the ligand structure while the embedded red colors showed oxygen moiety. The binding pocket interacted residues are highlighted in dark red color and black dotted lines justify the hydrogen bondings. Two hydrogen binds were observed with HIS374 at a distances of 3.64 and $3.54 \AA$ and one with HIS372 at a distance $3.68 \AA$, respectively.

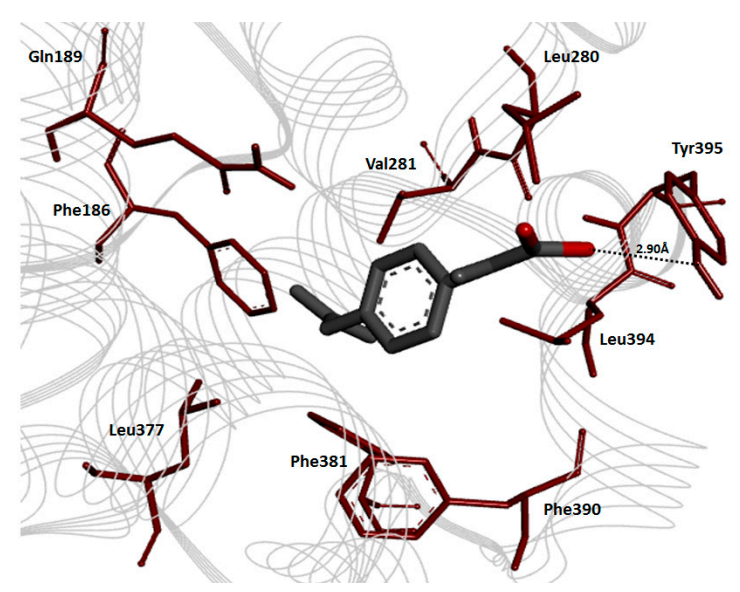

Figure 7. Docking interactions of dexibuprofen with receptor. The COX-2 protein chain is highlighted in light grey color in wire format. The dark grey color showed the dexibuprofen structure while the embedded red colors showed oxygen moiety. The binding pocket interacted residues are highlighted in dark red color and black dotted lines justify the hydrogen bondings.

\subsection{Molecular Dynamics (MD) Simulations Analysis}

To evaluate the residual flexibility and structural behavior of target protein, we incorporated $\mathbf{5 a - c}$ docking complexes in Gromacs 4.5.4 and performed MD at 5 ns. The Root Mean Square Deviation (RMSD) played a significant role in protein stability [40]. The generated RMSD graphs of all three complexes 5a-c depicted the backbone flexibility of the targeted protein (Figure 8). Furing the over all simulation period, RMSD increasing trend was observed in all three complexes from 0 to $1000 \mathrm{ps}$. In 5a simulation, the RMSD increased and stabilized at 1000 ps. It remained stable in the simulation period from 1000 to 4000 ps, but showed a little increasing trend at $5000 \mathrm{ps}$. In case of $5 \mathbf{b}$ complex, the RMSD graph is increased gradually from 0 to $1000 \mathrm{ps}$ and then gains stability throughout the simulation period. However, prodrug $5 \mathrm{c}$ RMSD graph showed an increasing trend from 0 to $1500 \mathrm{ps}$ and then remains stable in the simulation period with little fluctuations. From the RMSD analysis, the $\mathbf{5 b}$ structure seemed more stable compared to the $5 \mathbf{a}$ and $\mathbf{5 c}$ structures due to lower fluctuation of RMSD from 1000 to 5000 ps. The predicted results showed that attachment of prodrugs at the active site of the protein does not disturb the protein backbone stability. The dexibuprofen RMSD 
value was calculated by match maker command in Chimera tool. The dexibuprofen docked structure was superimposed against the crystal structure. The predicted RMSD value (0-1 $\mathrm{A})$ of the docked dexibuprofen structure showed the efficient binding within the active binding site. It has been reported that the higher RMSD value showed more deviation from the template structure [41].

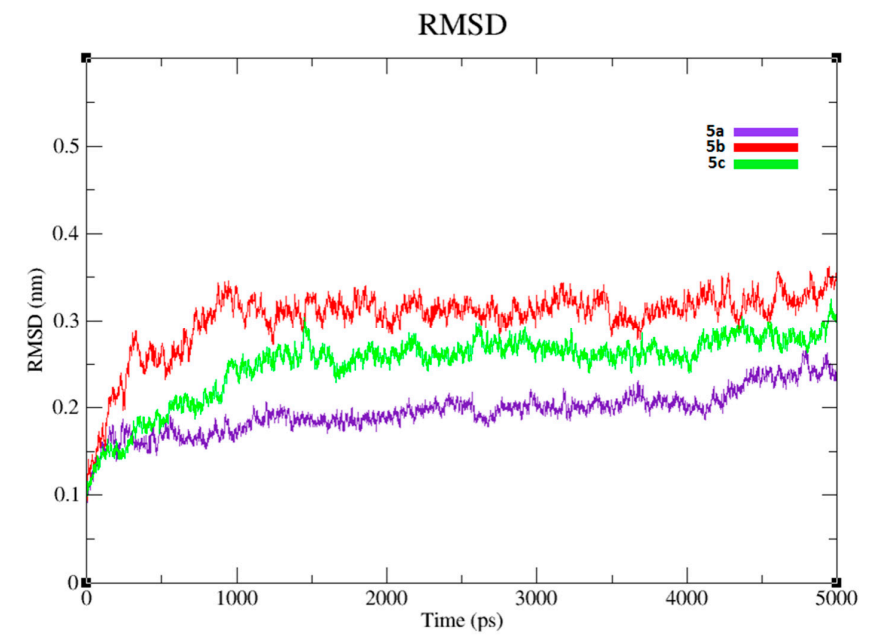

Figure 8. Root Mean Square Deviation (RMSD) graphs of (5a-c) complexes at different time scale. The backbones with indigo, red and green represent $(5 \mathbf{a}-\mathbf{c})$ complexes, respectively.

The residual fluctuations in the 5a-c docking complexes were observed by Root Mean Square Fluctuation (RMSF). The predicted RMSF graphs of C- $\alpha$ atom of all three complexes were plotted against the interacted residues based on the trajectory period of MD simulation. All the residues in docking complexes were fluctuated around $0.1-0.3 \mathrm{~nm}$ in the simulation period. All of the prodrugs showed little changes in residual fluctuation at different loop regions. The RMSF results also reflect that $\mathrm{N}$-terminal lobe of COX-2 is exhibited more fluctuations than C-terminus (Figure 9). The compactness of protein was observed by radius of gyration $\left(R_{\mathrm{g}}\right)$. The predicted results of COX-2 justified that $R_{\mathrm{g}}$ value is little fluctuated between 2.3 and $2.4 \mathrm{~nm}$ throughout the simulation time $0-5000 \mathrm{ps}$. The comparative results showed that residual backbone and folding of COX-2 was steadily stable after binding the inhibitor $\mathbf{5 b}$ compared to others (Figure 10).

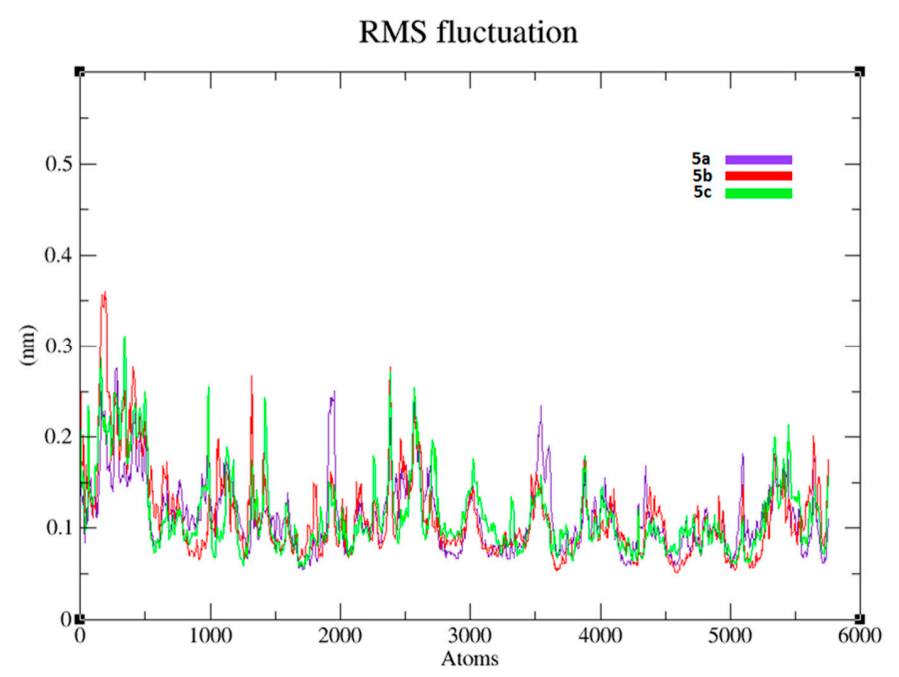

Figure 9. Root Mean Square Fluctuations (RMSF) graph of (5a-c) complexes at different time scale. The backbones with indigo, red and green represent the (5a-c) complexes, respectively. 
Radius of gyration

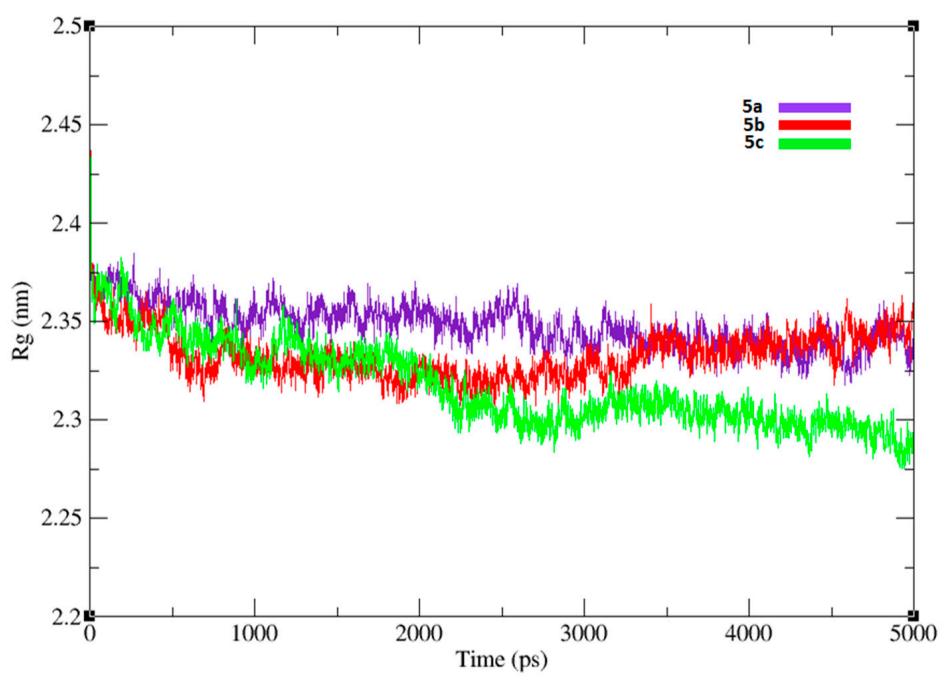

Figure 10. Radius of gyration $\left(R_{\mathrm{g}}\right)$ graph of prodrugs $(5 \mathbf{a}-\mathbf{c})$.

\section{Material and Methods}

\subsection{Chemicals}

Formalin (MERCK, Darmstadt, Germany), Carrageenan (Sigma Chemical Company. St. Louis, MO, USA), Dried yeast (Sigma Chemical Company), and Normal saline $(0.9 \% \mathrm{NaCl})$ were used.

\subsection{Experimental}

The digital Gallenkamp (SANYO, Calgary, AB, Canada) melting point apparatus model MPD BM 3.5 was used to determine the melting points. The FTS 3000MX and Bruker AM-300 spectrophotometers were used for FTIR and NMR spectral analysis. The ${ }^{1} \mathrm{H}-\mathrm{NMR}$ and ${ }^{13} \mathrm{C}-\mathrm{NMR}$ spectral analysis were performed as $\mathrm{CDCl}_{3}$ solutions. The Agilent 6460 Series Triple Quadrupole instrument (Agilent, Santa Clara, CA, USA) was used to determine the molecular masses of the synthesized prodrugs. The electrospray ionization technique in the positive ion mode (ESI+) was employed for ionization. The purity of the final products was ascertained by preparative thin layer chromatography (TLC) on silica gel HF-254.

\subsection{Synthesis of Antioxidant Chloroacetyl Derivatives ( $3 a-c)$}

General Procedure

Antioxidants $(0.01 \mathrm{~mol})$ and triethylamine $(0.01 \mathrm{~mol}, 1.0 \mathrm{~mL})$ were dissolved in anhydrous dichloromethane $(25 \mathrm{~mL})$ at 0 to $-5{ }^{\circ} \mathrm{C}$. To this solution, chloroacetyl chloride $(0.01 \mathrm{~mol}, 0.0796 \mathrm{~mL})$ in dry dichloromethane was added drop wise over a period of $1 \mathrm{~h}$ maintaining the temperature constant. The reaction mixture was stirred for $5 \mathrm{~h}$ at room temperature. After the completion of reaction the products were extracted with ethyl acetate and washed with $5 \% \mathrm{HCl}, 5 \%$ sodium hydroxide and with saturated $\mathrm{NaCl}$ solution. The ethyl acetate layer was rotary evaporated to afford the antioxidant chloroacetyl derivatives. All of the antioxidant chloroacetyl derivatives $3 a-c$ were synthesized starting with natural antioxidants $\mathbf{2} \mathbf{a}-\mathbf{c}$ by employing this general procedure. The synthesized compounds $3 \mathbf{a}-\mathbf{c}$ were purified by recrystallization in petroleum ether and ethyl acetate mixture (2:1).

Synthesis of 2-isopropyl-5-methylcyclohexyl chloromethanoate 3a. Yield 71\%, solid, m.p. $38-40{ }^{\circ} \mathrm{C}, R_{\mathrm{f}} 0.55$ (pet. ether:ethyl acetate 3:1), IR $v_{\max } \mathrm{cm}^{-1}(\mathrm{KBr}): 2961(\mathrm{C}-\mathrm{H}), 1739$ (C=O ester), $1511(\mathrm{C}=\mathrm{C}), 1196$ $(\mathrm{C}-\mathrm{O}), 788(\mathrm{C}-\mathrm{Cl})$. 
Synthesis of 3,4-(methylenedioxy)phenyl chloromethanoate $3 \mathbf{b}$. Yield $82 \%$, solid, m.p. $46-48{ }^{\circ} \mathrm{C}, R_{\mathrm{f}} 0.6$ (pet. ether:ethyl acetate 3:1), IR $\gamma_{\max } \mathrm{cm}^{-1}(\mathrm{KBr}): 2941(\mathrm{C}-\mathrm{H}), 1767$ (C=O ester), $1510(\mathrm{C}=\mathrm{C}), 1165(\mathrm{C}-\mathrm{O})$, $837(\mathrm{C}-\mathrm{Cl})$.

Synthesis of 2-oxo-2H-chromen-7-ylchloroethanoate 3c. Yield 81\%, solid, m.p. $36-38{ }^{\circ} \mathrm{C}, R_{\mathrm{f}} 0.59$ (pet. ether:ethyl acetate 3:1), IR $v_{\max } \mathrm{cm}^{-1}(\mathrm{KBr}): 2945(\mathrm{C}-\mathrm{H}), 1767$ (C=O ester), $1511(\mathrm{C}=\mathrm{C}), 1154(\mathrm{C}-\mathrm{O})$, $788(\mathrm{C}-\mathrm{Cl})$.

\subsection{Synthesis of Dexibuprofen Antioxidant Mutual Prodrugs $5 \boldsymbol{a}-\boldsymbol{c}$}

General Procedure

Antioxidant chloroacetyl derivatives $(0.01 \mathrm{~mol})$ and dexibuprofen $(4 ; 2.06 \mathrm{~g}, 0.01 \mathrm{~mol})$ were dissolved in dimethylformamide DMF $(25 \mathrm{~mL})$. Triethyl amine $(0.01 \mathrm{~mol}, 1.0 \mathrm{~mL})$ and potassium iodide $(0.01 \mathrm{~mol}, 1.66 \mathrm{~g})$ were added to the reaction mixture and stirred it overnight at room temperature. After the completion of reaction the mixture was poured into ice cold water and extracted with chloroform $(4 \times 25 \mathrm{~mL})$. The combined organic layer was washed with $2 \%$ sodium thiosulfate, $5 \% \mathrm{HCl}, 5 \%$ sodium hydroxide and finally with brine solution. The organic layer was dried over anhydrous sodium sulfate, filtered and the solvent was removed under reduced pressure to obtain the corresponding mutual prodrugs. The title mutual prodrugs $\mathbf{5 a - c}$ were synthesized by following the above-mentioned general procedure starting with different antioxidants chloroacetyl derivatives 3a-c (Scheme 1). The products were obtained as semisolids and were purified by preparative thin layer chromatography using petroleum ether and ethyl acetate as eluents (3:1).

Synthesis of (S)-((2-isopropyl-5-methyl-5-methylcyclohexyl) carbonyl) methyl 2-(4-isobutylphenyl) propanoata 5a. Yield 76.5\%, semisolid, $R_{\mathrm{f}} 0.64$ (pet. ether:ethyl acetate 3:1), IR $v_{\max } \mathrm{cm}^{-1}(\mathrm{KBr}): 2953(\mathrm{C}-\mathrm{H}), 1745$ (C=O ester), $1138\left(\mathrm{C}-\mathrm{O}\right.$, ester); ${ }^{1} \mathrm{H}-\mathrm{NMR}\left(\mathrm{CDCl}_{3}, \delta \mathrm{ppm}\right): 1.01(\mathrm{~d}, J=7.4 \mathrm{~Hz}, 6 \mathrm{H}, \mathrm{H}-7), 1.45$ (q, $J=7.8$ $\left.\mathrm{Hz}, 1 \mathrm{H}, \mathrm{H}-6^{\prime \prime}\right), 1.50\left(\mathrm{q}, J=4.1 \mathrm{~Hz}, 2 \mathrm{H}, \mathrm{H}-5^{\prime \prime}\right), 1.52\left(\mathrm{q}, J=4.0 \mathrm{~Hz}, 2 \mathrm{H}, \mathrm{H}-4^{\prime \prime}\right), 1.55(\mathrm{~d}, J=3.3 \mathrm{~Hz}, 6 \mathrm{H}, \mathrm{H}-1)$, $1.72\left(\mathrm{~m}, 1 \mathrm{H}, \mathrm{H}-3^{\prime \prime}\right), 1.76\left(\mathrm{t}, J=5.1 \mathrm{~Hz}, 2 \mathrm{H}, \mathrm{H}-2^{\prime \prime}\right), 1.78(\mathrm{~m}, 1 \mathrm{H}, \mathrm{H}-2), 1.82$ (septet, 1H, H-8), 2.25 (s, 3H, $\mathrm{H}-9), 2.43(\mathrm{~d}, J=7.2 \mathrm{~Hz}, 3 \mathrm{H}, \mathrm{H}-4), 2.88(\mathrm{~d}, J=4.5 \mathrm{~Hz}, 2 \mathrm{H}, \mathrm{H}-3), 2.95\left(\mathrm{q}, J=7.8 \mathrm{~Hz}, 1 \mathrm{H}, \mathrm{H}-\mathrm{-}^{\prime \prime}\right), 3.24$ (s, 2H, H-6), $4.55(\mathrm{q}, J=9.8 \mathrm{~Hz}, 1 \mathrm{H}, \mathrm{H}-5), 7.06\left(\mathrm{~d}, J=8.1 \mathrm{~Hz}, 2 \mathrm{H}, \mathrm{H}-2^{\prime}\right), 7.24\left(\mathrm{~d}, J=7.2 \mathrm{~Hz}, 2 \mathrm{H}, \mathrm{H}-1^{\prime}\right)$; ${ }^{13} \mathrm{C}-\mathrm{NMR}\left(\mathrm{CDCl}_{3}, \delta \mathrm{ppm}\right): 26.15$ (C-1), 31.65 (C-2), 44.63 (C-3), 25.89 (C-4), 40.63 (C-5), 167.38 (C-6), 50.18 (C-7),174.04 (C-8), 25.89 (C-9), 30.13 (C-10), 23.41 (C-11), 140.05 (C-1'), 127.23 (C-2'), 129.35 (C-3'), $137.17\left(\mathrm{C}-4^{\prime}\right), 61.11\left(\mathrm{C}-1^{\prime \prime}\right), 34.15\left(\mathrm{C}-2^{\prime \prime}\right), 31.43\left(\mathrm{C}-3^{\prime \prime}\right), 34.58\left(\mathrm{C}-4^{\prime \prime}\right), 31.37\left(\mathrm{C}-5^{\prime \prime}\right), 46.83\left(\mathrm{C}-6^{\prime \prime}\right)$; ESI-MS: $m / z 425(43 \%)(\mathrm{M}+23)(\mathrm{M}+\mathrm{Na}), 247(23 \%), 189(100 \%), 161(62 \%), 155(43 \%), 133(31 \%)$.

Synthesis of (S)-((benzo(D)-(1,3)dioxol-6-yloxy) carbonyl) methyl-2-(4-isobutylphenyl) propanoate 5b. Yield $72.9 \%$, semisolid, $R_{\mathrm{f}} 0.70$ (pet. ether:ethyl acetate 3:1), IR $v_{\max } \mathrm{cm}^{-1}(\mathrm{KBr}): 2957(\mathrm{C}-\mathrm{H}), 1735(\mathrm{C}=\mathrm{O}$ ester), 1147 (C-O, ester), 1105 (C-O ether); ${ }^{1} \mathrm{H}-\mathrm{NMR}\left(\mathrm{CDCl}_{3}, \delta \mathrm{ppm}\right): 1.05(\mathrm{~d}, J=6.1 \mathrm{~Hz}, 6 \mathrm{H}, \mathrm{H}-1), 2.11$ $(\mathrm{m}, 1 \mathrm{H}, \mathrm{H}-2), 2.20(\mathrm{~d}, J=6.6 \mathrm{~Hz}, 3 \mathrm{H}, \mathrm{H}-4), 2.67(\mathrm{~d}, J=7.2 \mathrm{~Hz}, 2 \mathrm{H}, \mathrm{H}-3), 3.78(\mathrm{q}, J=9.8 \mathrm{~Hz}, 1 \mathrm{H}, \mathrm{H}-5), 4.89$ (s, 2H, H-6), $5.80(\mathrm{~s}, 2 \mathrm{H}, \mathrm{H}-7), 6.40\left(\mathrm{~s}, 1 \mathrm{H}, \mathrm{H}-3^{\prime \prime}\right), 6.53\left(\mathrm{~d}, J=7.7 \mathrm{~Hz}, 1 \mathrm{H}, \mathrm{H}-1^{\prime \prime}\right), 6.72(\mathrm{~d}, J=8.1 \mathrm{~Hz}, 1 \mathrm{H}$, $\left.\mathrm{H}-2^{\prime \prime}\right), 7.15\left(\mathrm{~d}, J=7.8 \mathrm{~Hz}, 2 \mathrm{H}, \mathrm{H}-2^{\prime}, \mathrm{H}-3^{\prime}\right), 7.24\left(\mathrm{~d}, J=8.1 \mathrm{~Hz}, 2 \mathrm{H}, \mathrm{H}-1^{\prime}, \mathrm{H}-4^{\prime}\right) ;{ }^{13} \mathrm{C}-\mathrm{NMR}\left(\mathrm{CDCl}_{3}, \delta \mathrm{ppm}\right)$ : 20.81 (C-1), 23.43 (C-2), 44.62 (C-3), 18.24 (C-4), 43.25 (C-5), 61.90 (C-6), 157.64 (C-7), 160.90 (C-8), 99.82 (C-9), $137.21\left(\mathrm{C}-1^{\prime}\right), 128.00\left(\mathrm{C}-2^{\prime}, \mathrm{C}-6^{\prime}\right), 128.35\left(\mathrm{C}-3^{\prime}, \mathrm{C}-5^{\prime}\right), 131.01\left(\mathrm{C}-4^{\prime}\right), 143.70\left(\mathrm{C}-1^{\prime \prime}\right), 112.29\left(\mathrm{C}-2^{\prime \prime}\right)$, $113.74\left(\mathrm{C}-3^{\prime \prime}\right), 144.81\left(\mathrm{C}-4^{\prime \prime}\right), 148.92\left(\mathrm{C}-5^{\prime \prime}\right), 105.43\left(\mathrm{C}-6^{\prime \prime}\right)$; ESI-MS: $m / z 407(39 \%)(\mathrm{M}+23)(\mathrm{M}+\mathrm{Na})$, 247 (25\%), 189 (100\%), 161 (54\%), 137 (37\%), 133 (26\%).

Synthesis of (S)-((2-oxo-2H-chromen-7-yloxy) carbonyl) methyl 2-(4-isobutylphenyl) propanoate 5c. Yield 68\%, semisolid, $R_{\mathrm{f}} 0.75$ (pet. ether:ethyl acetate 3:1), IR $v_{\max } \mathrm{cm}^{-1}(\mathrm{KBr}): 2957(\mathrm{C}-\mathrm{H}), 1730(\mathrm{C}=\mathrm{O}$ ester), $1142\left(\mathrm{C}-\mathrm{O}\right.$, ester); ${ }^{1} \mathrm{H}-\mathrm{NMR}\left(\mathrm{CDCl}_{3}, \delta \mathrm{ppm}\right): 1.49(\mathrm{~d}, J=6.5 \mathrm{~Hz}, 3 \mathrm{H}, \mathrm{H}-4), 1.53(\mathrm{~d}, J=5.8 \mathrm{~Hz}, 6 \mathrm{H}$, H-1), $2.22(\mathrm{~m}, 1 \mathrm{H}, \mathrm{H}-2), 2.66(\mathrm{~d}, J=6.8 \mathrm{~Hz}, 2 \mathrm{H}, \mathrm{H}-3), 4.25$ (q, $J=9.3 \mathrm{~Hz}, 1 \mathrm{H}, \mathrm{H}-5), 5.13$ (s, 2H, H-6), $6.15\left(\mathrm{~d}, J=6.1 \mathrm{~Hz}, 1 \mathrm{H}, \mathrm{H}-4^{\prime \prime}\right), 6.80\left(\mathrm{~d}, J=7.2 \mathrm{~Hz}, 1 \mathrm{H}, \mathrm{H}-1^{\prime \prime}\right), 6.83\left(\mathrm{~s}, 1 \mathrm{H}, \mathrm{H}-5^{\prime \prime}\right), 7.24(\mathrm{~d}, J=7.0 \mathrm{~Hz}, 1 \mathrm{H}$, $\left.\mathrm{H}-2^{\prime \prime}\right), 7.38\left(\mathrm{~d}, J=6.1 \mathrm{~Hz}, 1 \mathrm{H}, \mathrm{H}-3^{\prime \prime}\right), 7.39\left(\mathrm{~d}, J=8.7 \mathrm{~Hz}, 2 \mathrm{H}, \mathrm{H}-2^{\prime}, \mathrm{H}-6^{\prime}\right), 7.44\left(\mathrm{~d}, J=8.2 \mathrm{~Hz}, 2 \mathrm{H}, \mathrm{H}-1^{\prime}\right.$, $\left.\mathrm{H}-4^{\prime}\right) ;{ }^{13} \mathrm{C}-\mathrm{NMR}\left(\mathrm{CDCl}_{3}, \delta\right.$ ppm): 20.81 (C-1), 25.34 (C-2), 49.62 (C-3), 16.50 (C-4), 40.21 (C-5), 173.15 
(C-6), 69.29 (C-7), $174.44(\mathrm{C}-8), 137.73\left(\mathrm{C}-1^{\prime}\right), 128.12\left(\mathrm{C}-2^{\prime}\right), 129.39\left(\mathrm{C}-3^{\prime}\right), 131.42\left(\mathrm{C}-4^{\prime}\right), 150.01\left(\mathrm{C}-1^{\prime \prime}\right)$, $116.34\left(\mathrm{C}-2^{\prime \prime}\right), 125.21\left(\mathrm{C}-3^{\prime \prime}\right), 117.08\left(\mathrm{C}-4^{\prime \prime}\right), 140.64\left(\mathrm{C}-5^{\prime \prime}\right), 109.50\left(\mathrm{C}-6^{\prime \prime}\right), 160.92\left(\mathrm{C}-7^{\prime \prime}\right), 147.64\left(\mathrm{C}-8^{\prime \prime}\right)$, $108.28\left(\mathrm{C}-9^{\prime \prime}\right)$; ESI-MS: $m / z 431(36 \%)(\mathrm{M}+23)(\mathrm{M}+\mathrm{Na}), 247(30 \%), 189(100 \%), 161(63 \%), 134(49 \%)$, $133(32 \%)$.

\subsection{In Vitro Hydrolysis}

The in vitrohydrolytic studies of mutual prodrugs $5 \mathbf{a}-\mathbf{c}$ were performed in simulated fluid ( $\mathrm{pH} 1.2$ and 7.4) and in 80\% human plasma ( $\mathrm{pH}$ 7.4). These simulated fluids i.e., simulated gastric fluid (SGF pH 1.2) and simulated intestinal fluid (SIF pH 7.4) are extensively utilized in pharmaceutical industries for dissolution tests. Hydrochloric acid solution and potassium phosphate monobasic were used to prepare these media. The simulated gastric fluid is prepared by mixing the $0.2 \mathrm{M}$ aqueous potassium chloride with a $0.2 \mathrm{M}$ hydrochloric acid solution. The SGF was degassed after adjusting the final $\mathrm{pH}$. The monobasic potassium phosphate buffer was prepared in water and final $\mathrm{pH} 7.4$ was adjusted by slow addition of potassium hydroxide solution. To prepare the stock solution, $10 \mathrm{mg}$ of each prodrug was mixed in $90 \mathrm{~mL}$ of SGF ( $\mathrm{pH} 1.2$ ) or SIF ( $\mathrm{pH} 7.4$ ). The $15 \mathrm{~mL}$ of this stock solution was taken repeatedly and kept in test tubes maintained at $37 \pm 0.5^{\circ} \mathrm{C}$. From these test tubes some solution was taken after a fixed time interval ( $0.5,1,2$ up to $8 \mathrm{~h}$ ) and was transferred to micro centrifuge tubes. The solution was then centrifuged at high speed (3000 rpm) for $5 \mathrm{~min}$ and clear supernatant was obtained. The amount of dexibuprofen released was then measured on UV spectrophotometer (Shimadzu, NAKAGYO-KU, Kyoto 604-8511, Japan) after hydrolysis in buffer solutions at 230-215 and $280-260 \mathrm{~nm}$ respectively.

\subsection{Pharmacology}

Animals

The animals used for this study were 20-30 g weight mice either male or female and were housed at animal house department of Pharmacology, University of Sargodha. Animals were provided standard diet and water at libitum. All animals were treated according to instructions of National Institute of Health (NIH) guidelines. The study protocol was approved by the ethical Committee, Faculty of Pharmacy, University of Sargodha in the month of June 2014 vide project approval number PHRM-UOS-125.

\subsection{Animal Care}

\subsubsection{Temperature and Humidity}

The temperature range of animal house was $26-34{ }^{\circ} \mathrm{C}$ and relative humidity was kept in a controlled range of $30 \%$ to $70 \%$.

\subsubsection{Ventilation and Air Quality}

The proper ventilation was provided to animals with quality air and stable environment. Animals were avoided from direct exposure to high velocity air (drafts) during the experiment. Heating, ventilation, and air conditioning (HVAC) systems were used to maintain the ventilation rates in accordance with heat load and other variables. Ten to fifteen fresh air changes per hour in animal house were acquired to maintain macro-environmental air quality by constant volume systems and may also ensure micro-environmental air quality.

\subsubsection{Drug Administration}

The solutions/suspensions of drugs were administered to the animals by either oral or subcutaneous routes. For oral administration oral gavage tube was used while for subcutaneous administration syringe was used. 


\subsection{Anti-Inflammatory Activity}

Carrageenan Induced Paw Edema in Mice

Anti-inflammatory activity of mutual prodrugs $\mathbf{5 a - c}$ was determined by following the already reported method by slight modification against carrageenan induced paw edema in mice [42]. The animals were distributed into 5 groups each having five mice. The mice used for the experiment were kept on fasting for $24 \mathrm{~h}$ before the starting of experiment. The animals in Group I were treated with normal saline $10 \mathrm{~mL} / \mathrm{kg}$ p.o. (per oral) served as control group and Group II was treated with standard dexibuprofen $20 \mathrm{mg} / \mathrm{kg}$ p.o. The animals of Groups III, IV and V were treated with prodrugs $\mathbf{5 a - c}$, respectively, as $20 \mathrm{mg} / \mathrm{kg}$ p.o. The inflammation was induced after $1 \mathrm{~h}$ administration of prodrugs by injecting $0.1 \mathrm{~mL}$ freshly prepared carrageenan suspension $(1 \%)$ in normal saline into the sub planar surface of the right hind paw. The paw volume was measured at $0,1,2,3$ and $4 \mathrm{~h}$ after the administration of carrageenan by using vernier caliper.

$$
\text { Percent inhibition }(\%)=100(1-X / Y)
$$

where $X=$ mean increase in paw thickness of treated mice; and $Y=$ mean increase in paw thickness of control mice.

\subsection{Albumin Induced Inflammation in Mice}

Anti-inflammatory potential of synthesized prodrugs $\mathbf{5 a - c}$ against egg albumin induced inflammation was also determined for further verification by following the previously reported method [43]. The animals were divided into five groups, each group having five animals. The animals were kept on fasting for $24 \mathrm{~h}$ before the beginning of the experiment. The mice in control group (Group I) were treated with normal saline $10 \mathrm{~mL} / \mathrm{kg}$ p.o. and animals of Group II were treated with dexibuprofen $20 \mathrm{mg} / \mathrm{kg}$ p.o. The synthesized prodrugs 5a-c were given to Groups III-V, respectively, as $20 \mathrm{mg} / \mathrm{kg}$ p.o. After $1 \mathrm{~h}$ of treatment, $0.1 \mathrm{~mL}$ of fresh egg albumin was injected into the paw for the induction of inflammation and the paw volume was calculated at 0, 1,2 and $3 \mathrm{~h}$ after the administration of inflammatory agent.

\subsection{Analgesic Activity}

\subsubsection{Acetic Acid Induced Writhing in Mice}

Koster et al., reported method was adopted for the determination of analgesic activity of the mutual prodrugs $\mathbf{5 a - c}$ [44]. The mice were divided in to five groups each group consists of five animals. The control group (Group I) was treated with $10 \mathrm{~mL} / \mathrm{kg}$ normal saline p.o. while Group II was treated with dexibuprofen $20 \mathrm{mg} / \mathrm{kg}$ p.o. The synthesized mutual prodrugs $5 \mathbf{a}-\mathbf{c}(20 \mathrm{mg} / \mathrm{kg}$ p.o.) were given to Groups III-V, respectively. For induction of writhings, acetic acid solution ( $0.6 \%$ in normal saline) was given to every mouse post $30 \mathrm{~min}$ of treatment. After $5 \mathrm{~min}$ of injection of this solution, the number of writhings was counted up to $15 \mathrm{~min}$. The analgesic activity of synthesized mutual prodrugs $\mathbf{5 a - c}$ and dexibuprofen was determined by comparing the results with those of the animals in the control group.

\subsubsection{Formalin Induced Licking in Mice}

Formalin induced licking in mice was also used to determine analgesic activity of prodrugs 5a-c for further verification [45]. The animals were distributed in to five groups having five mice in each group. Group I served as control group was treated with $10 \mathrm{~mL} / \mathrm{kg}$ normal saline p.o. while Group II was treated with dexibuprofen $20 \mathrm{mg} / \mathrm{kg}$ p.o. The prodrugs $5 \mathrm{a}-\mathrm{c}(20 \mathrm{mg} / \mathrm{kg}$ p.o.) were administered to Groups III-V, respectively. Formalin $(0.05 \mathrm{~mL}, 2.5 \%)$ was injected into sub-planter of right hind paw and responses were observed for $30 \mathrm{~min}$. 


\subsection{Antipyretic Activity}

Antipyretic activity of prodrugs $\mathbf{5 a - c}$ was evaluated against yeast induced pyrexia in mice according to Sakande et al., reported method [46]. Aqueous suspension of brewer's yeast $(20 \%$ in distilled water) $10 \mathrm{mg} / \mathrm{kg}$ was given subcutaneous to mice. The rectal temperatures of mice were noted after $16 \mathrm{~h}$ of administration of brewer's yeast. Only, those animals were further used in which the pyrexia had been induced. The animals were divided in to five groups having five mice in each group. The Group I (control group) was treated with $10 \mathrm{~mL} / \mathrm{kg}$ normal saline p.o. while Group II (Standard Group) was treated with dexibuprofen $20 \mathrm{mg} / \mathrm{kg}$ p.o. The prodrugs $5 \mathrm{a}-\mathrm{c}(20 \mathrm{mg} / \mathrm{kg}$ p.o.) were administered to Groups III-V, respectively. Then animals were treated as described earlier with control, standard and prodrugs 5a-c. Rectal temperature of animals was recorded at 1, 2, 3 and $4 \mathrm{~h}$ after drug administration.

\subsection{Ulcerogenic Studies}

The ulcerogenic potential of dexibuprofen and synthesized mutual prodrugs $5 \mathbf{a}-\mathbf{c}$ were determined by following the fasted rat model. The animals were categorized into 6 groups, each has 5 animals. Group 1 was control and given $0.5 \%$ carboxymethyl cellulose (CMC) suspension. The standard dexibuprofen at a dose of $20 \mathrm{mg} / \mathrm{kg}$ p.o. was given to group II. The prodrugs $5 \mathbf{a}-\mathbf{c}$ ( $20 \mathrm{mg} / \mathrm{kg}$ p.o.) were given to Groups III-V, respectively. Food and water was removed from animal cages $24 \mathrm{~h}$ before starting the experiments. After $4 \mathrm{~h}$ administration of dose, the animal's stomach was removed by sacrificing the animal. Stomach was kept on saline soaked filter paper for inspection. The stomach was opened along larger curvature and cleaned with distilled water. The mucous was removed and the area of ulcers and stomachs were noted [47,48].

Following formula was used for calculation of Ulcer index (UI) [49];

$$
U I=\frac{\text { Area of Ulcer }}{\text { Area of Stomach }} \times 100
$$

\subsection{Ex Vivo Antiplatelet Aggregation Activity}

The antiplatelet activity of synthesized mutual prodrugs $\mathbf{5 a - c}$ was investigated by following the already reported method with some modifications [50]. Male Sprague-Dawley (SD) rats weighing 320-350 g were used after overnight fasting. Rats were orally administered via gastric tube $100 \mathrm{mg} / \mathrm{kg}$ of prodrugs solution or $50 \mathrm{mg} / \mathrm{kg}$ of acetyl salicylic acid (ASA) suspended in $0.5 \%$ carboxymethyl cellulose (CMC) solution. Blood was collected $90 \mathrm{~min}$ after sample administration and platelet-rich plasma (PRP) was prepared by centrifugation of blood at $120 \times \mathrm{g}$ for $15 \mathrm{~min}$ and further centrifuged at $850 \times g$ for $15 \mathrm{~min}$ to prepare platelet-poor plasma (PPP). Platelet aggregation was induced by $32.8 \mu \mathrm{g} / \mathrm{mL}$ of collagen or $1.3 \mu \mathrm{mol} / \mathrm{L}$ of adenosine diphosphate (ADP) in $300 \mu \mathrm{L}$ of PRP. The PRP $(300 \mu \mathrm{L})$ was incubated at $37^{\circ} \mathrm{C}$ for $2 \mathrm{~min}$ in the aggregometer with stirring at $1000 \mathrm{rpm}$ and then stimulated with ADP, collagen, epinephrine and A23187. The changes in light transmission were recorded for $5 \mathrm{~min}$ after stimulation. The synthesized mutual prodrugs $5 \mathbf{a}-\mathbf{c}$ were added to the platelet suspension $3 \mathrm{~min}$ before the addition of the aggregating agents. The extent of inhibition of platelet aggregation is expressed as percent inhibition $(X)$ using the following formula:

$$
X=((A-B) / A) \times 100
$$

where $A$ = maximal aggregation of the control; and $B=$ maximal aggregation of sample-treated PRP.

\subsection{Statistical Analysis}

The results are expressed as means \pm SEM and Parametric data were compared to control group. One-way ANOVA followed by Dunnet's test and two way ANOVA followed by Bonferroni post-test were applied to assess the data. Values of $p<0.05$ were considered as statistically significant. 


\subsection{Protein Structure from $P D B$}

The three dimensional crystal structure of mice cyclooxygenase-2 (COX-2) was retrieved from the Protein Data Bank (PDB) with PDBID 3NTG. The overall stereo-chemical properties of cyclooxygenase-2 structure and Ramachandran graph and values [51] were assessed by Molprobity server [52].

\subsection{Prodrugs Preparation}

The parent dexibuprofen and prodrugs $5 \mathbf{a}-\mathbf{c}$ were sketched in ACD/ChemSketch tool. The designed structures were further visualized and minimized by UCSF Chimera 1.10.1 [53]. The Molinspiration (Available online: http://www.molinspiration.com/) and Molsoft (Available online: http://www.molsoft.com/) online computational tools were applied to predict the drug-likeness and basic biological properties of synthesized prodrugs. Moreover, Lipinski's rule of five was analyzed using Molsoft and Molinspiraion tools. The number of rotatable bonds, H-bond acceptors (HBA) and H-bond donors (HBD) were also confirmed by PubChem (Available online: https://pubchem.ncbi.nlm.nih.gov/).

\subsection{Grid Generation and Molecular Docking}

The structure of target enzyme COX-2 was prepared and optimized to perform molecular docking studies. Hydrogen atoms were added to the target enzyme and bond order was also assigned. Molecular docking was carried out and different docked complexes were visualized by PyRx tool (vina wizard) [54]. The grid box parametric central values of $X=28.6432, Y=28.6975$ and $Z=9.4725$, while, size of $X=59.75, Y=77.94$ and $Z=63.86$, respectively, with spacing $1.0 \AA$ and exhaustiveness values were adjusted to attain the finest binding conformational poses of ligand molecules. The maximum docking poses (100 runs) for each docking were adjusted to get the best docking complex with good conformational pose. All the synthesized mutual prodrugs $5 \mathbf{a}-\mathbf{c}$ and dexibuprofen were docked separately against crystal structure of COX-2 and the obtained docked complexes were further evaluated on lowest binding energy $(\mathrm{kcal} / \mathrm{mol})$ values. Docking analysis was employed by Discovery Studio (2.1.0) [55] and UCSF Chimera 1.10.1.

\subsection{Molecular Dynamics (MD) Simulation}

The best docked energy (Kcal/mol) complexes were selected for molecular dynamics (MD) simulation through Groningen Machine for Chemicals Simulations (GROMACS) 4.5.4 package [56] with GROMOS 53A6 force field and water model SPC216 [57]. The topology files (receptor and ligand) were produced by using GROMOS 53A6 force-field and online PRODRG Server [58], respectively. Furthermore, all the receptor-ligand complexes were solvated and placed in the center of cubic box with an adjusted minimum $0.9 \AA$ distance. To neutralize the system charge ions were added before the energy minimization. Energy minimization (nsteps $=50,000$ ) was done by steepest descent method (1000 ps) and energy calculation was done by Particle Mesh Ewald (PME) method [59], while for covalent bond constraints linear constraint solver (LINCS) algorithm was used [60]. The NVT analysis was also applied for $100 \mathrm{ps}$ at a fixed volume, pressure (1atm) and temperature ( $300 \mathrm{~K})$ to equilibrate the system with protein and ligands [61]. The final MD run was set to 5000 ps with nsteps 2,500,000 for each protein-ligand complexes and trajectories files analysis was done using Xmgrace (Available online: http://plasma-gate.weizmann.ac.il/Grace/).

\section{Conclusions}

The present work utilizes safer promoieties, i.e., natural antioxidants, for the synthesis of dexibuprofen prodrugs $\mathbf{5 a - c}$. The spectroscopic data of these prodrugs confirmed their structures. All synthesized mutual prodrugs showed encouraging hydrolysis rate in SIF $+80 \%$ human plasma probably due to the presence of esterase enzymes in plasma. The synthesized prodrugs are stable in 
gastric mucosa at $\mathrm{pH} 1.2$ and are not hydrolyzed to free dexibuprofen. On the other hand, in simulated intestinal fluid $\mathrm{pH} 7.4,18 \%$ of the prodrugs are hydrolyzed to free drug. The prodrugs synthesis also prevents the accumulation of drug in gastric mucosa, resultingin decreased GI irritation without the loss of pharmacological response. The molecular docking and simulation studies also proved that prodrugs formed stable complexes with the Cox-2 protein, thus supporting our wet lab results. The ulcerogenic activity and ex vivo antiplatelet aggregation activity results confirmed that synthesized prodrugs are less irritant to gastrointestinal mucosa than dexibuprofen. It is concluded, therefore, that the synthesized prodrugs have promising pharmacological activities with reduced gastrointestinal adverse effects compared to the parent drug.

Supplementary Materials: Supplementary materials can be found at www.mdpi.com/1422-0067/17/12/2151/s1.

Acknowledgments: This work was supported by a grant from the National Research Foundation of Korea (NRF) (MEST) (NRF-2014R1A1A3049653) and the Korean Health Technology R\&D Project, Ministry of Health \& Welfare, Republic of Korea (A120960-1201-0000300).

Author Contributions: Zaman Ashraf, Alamgeer, and Song Ja Kim supervised the study, designed the experiment and wrote the manuscript. Raqiqatur Rasool performed the experiment to synthesize the title compounds. Zaman Ashraf, Alamgeer, and Raqiqatur Rasool characterize the compounds and wrote the manuscript. Haseeb Ahsan, Samina Afzal and Khurram Afzal performed the in vivo studies. Mubashir Hassan and Zaman Ashraf designed the in silico experiment and helped in performing the docking studies of the title compounds. Mubashir Hassan performed the molecular dynamic simulation studies. All authors read and approved the final manuscript.

Conflicts of Interest: The authors declare no conflict of interest.

\section{References}

1. Gabard, B.; Nirnberge, G.; Schiel, H.; Mascher, H.; Kikuta, C.; Mayer, J.M. Comparison of the bioavailability of dexibuprofen administered alone or as part of racemic ibuprofen. Eur. J. Clin. Pharmacol. 1995, 48, 505-511. [CrossRef] [PubMed]

2. Bonabello, A.; Galmozzi, M.R.; Canaparo, R.; Isaia, G.C.; Serpe, L.; Muntoni, E.; Zara, G.P. Dexibuprofen $(S(+)$-isomer ibuprofen) reduces gastric damage and improves analgesic and antiinflammatory effects in rodents. Anaesth. Analg. 2004, 97, 402-408. [CrossRef]

3. Walser, S.; Hruby, R.; Hesse, E.; Heinzl, H.; Mascher, H. Preliminary toxicokinetic study with different crystal forms of $S(+)$-ibuprofen (dexibuprofen) and R,S-ibuprofen in rats. Arzneimittelforschung 1997, 47, 750-754. [PubMed]

4. Kaehler, S.T.; Phleps, W.; Hesse, E. Dexibuprofen: Pharmacology, therapeutic uses and safety. Inflamm. Pharm. 2003, 11, 371-383. [CrossRef] [PubMed]

5. Benu, M.; Sharma, P.D. Design, synthesis and evaluation of diclofenac-antioxidant mutual prodrugs as safer NSAIDs. Indian J. Chem. 2009, 48B, 1279-1287.

6. Polonia, J. Interaction of antihypertensive drugs with antiinflammatory drugs. J. Cardiol. 1997, 88, 47-51.

7. Rasheed, A.; Aishwarya, K.; Basha, N.; Reddy, B.S.; Swetha, A. Dexibuprofen-dextran macromolecular prodrugs: Synthesis, characterization and pharmacological evaluation. Der Pharm. Chem. 2009, 2, 124-132.

8. Bernard, S. Profile and mechanism of gastrointestinal and other side effects of non-steroidal antiinflammatory drugs (NSAIDs). Am. J. Med. 1999, 17, 27-35.

9. Peng, Y.S.; Lin, S.C.; Huang, S.J.; Wang, Y.M.; Lin, Y.J.; Wang, L.F.; Chen, J.S. Chondroitin sulfate-based anti-inflammatory macromolecular Prodrugs. Eur. J. Pharm. Sci. 2006, 1, 60-69. [CrossRef] [PubMed]

10. Zgoda, M.M.; Lukosek, M.; Nachajski, M.J. Micellarsolubilization of selected non-steroidal therapeutic agents by new surfaceactive agents of the class of the products of oxyethylation of ursodeoxycholic acid. Polim. Med. 2006, 4, 13-30.

11. Zhao, X.; Tao, X.; Wei, D.; Song, Q. Pharmacological activity and hydrolysis behavior of novel ibuprofen glucopyranoside conjugates. Eur. J. Med. Chem. 2006, 11, 1352-1358. [CrossRef] [PubMed]

12. Arun, R.; Ashok, K.C.K. Synthesis, hydrolysis and pharmacodynamic profiles of novel prodrugs of mefenamic acid. Int. J. Curr. Pharm. Res. 2009, 1, 47-55. 
13. Shanbhag, V.R.; Crider, A.M.; Gokhale, R.; Harpalani, A.; Dick, R.M. Ester and amide prodrugs of ibuprofen and naproxen: Synthesis, anti-inflammatory activity and gastrointestinal toxicity. J. Pharm. Sci. 2006, 81, 149-154. [CrossRef]

14. Khan, M.S.Y.; Akhter, M. Synthesis, pharmacological activity and hydrolyticbehavior of glyceride prodrugs of ibuprofen. Eur. J. Med. Chem. 2005, 40, 371-376. [CrossRef] [PubMed]

15. Chatterjee, N.R.; Kulkarni, A.A.; Ghulekar, S.P. Synthesis, pharmacological activity and hydrolytic behavior of ethylenediamine and benzathine conjugates of ibuprofen. Eur. J. Med. Chem. 2008, 43, 2819-2823. [CrossRef] [PubMed]

16. Shaaya, O.; Magora, A.; Sheskin, T.; Abraham, N.K.; Domb, J. Anhydride prodrugs for nonsteroidal anti-inflammatory drugs. Pharm. Res. 2003, 20, 205-211. [CrossRef] [PubMed]

17. Banekovich, C.; Ott, I.; Koch, T.; Matuszczak, B.; Gust, R. Synthesis and biological activities of novel dexibuprofen tetraacetyl riboflavin conjugate. Bioorg. Med. Chem. Lett. 2007, 17, 683-687. [CrossRef] [PubMed]

18. Ashraf, Z.; Imran, M.; Amin, S. Synthesis, characterization and in vitro hydrolysis studies of ester and amide prodrugs of dexibuprofen. Med. Chem. Res. 2012, 21, 3361-3368. [CrossRef]

19. Sharma, P.D.; Kaur, G.; Kansal, S.; Chandiran, S.K. Mutual prodrugs of 4-biphenylacetic acid and phytophenolics as safer NSAIDs: Synthetic and spectral studies. Indian J. Chem. Sect. B 2004, 43, 2159-2164.

20. Ashraf, Z.; Rafiq, M.; Seo, S.Y.; Kwon, K.S.; Babar, M.M.; Zaidi, N.S.S. Kinetic and in silico studies of novel hydroxy-based thymol analogues as inhibitors of mushroom tyrosinase. Eur. J. Med. Chem. 2015, 98, $203-211$. [CrossRef] [PubMed]

21. Kasahara, Y.K.; Yasukawa, S.; Kitanaka, M.; Khan, T.; Evans, F.J. Effect of methanol extract from flower petals of Tagetes patella L. on acute and chronic inflammation model. Phytother. Res. 2002, 16, 217-222. [CrossRef] [PubMed]

22. Vane, J.R. Inhibition of Prostaglandin Synthesis as a Mechanism of Action for Aspirin-like Drugs. Nat. New Biol. 1971, 231, 232-235. [CrossRef] [PubMed]

23. Linardi, A.; Costa, S.K.P.; Desilva, G.R.; Antunes, E. Involvement of kinins, mast cells and sensory neurons in the plasma exudation and paw edema induced by staphylococcal entrotoxin $B$ in the mouse. Eur. J. Pharmacol. 2002, 399, 235-242. [CrossRef]

24. Vasudevan, M.; Gunman, K.K.; Parle, M. Antinociceptive and anti-inflammatory effects of the spesiapopulnea bark extract. J. Ethnopharmacol. 2007, 109, 264-270. [CrossRef] [PubMed]

25. Rang, H.P.; Dale, M.M.; Ritter, J.M.; Flower, R.J. Rang \& Dale's Pharmacology, 6th ed.; Landon: Bethesda, MD, USA, 2007.

26. Bentley, G.A.; Newton, S.H.; Star, J.B. Studies on the anti-nociceptive action of $\alpha$-agonist drugs and their interaction with opoid mechanism. Br. J. Pharmacol. 1983, 79, 125-134. [CrossRef] [PubMed]

27. Deraedt, R.; Jongney, S.; Delevalcee, F.; Falhout, M. Release of prostaglandin E and F in an analgesic reaction and its inhibition. Eur. J. Pharmacol. 1980, 51, 17-24. [CrossRef]

28. Dhara, A.K.; Sube, V.; Sen, T.; Pal, A.N.; Chandhiri, A.K. Preliminary studies on the anti-inflammatory and analgesic activity of thmethanolic frictions of the root extract of Tragia involucrate. J. Ethnopharmacol. 2000, 72, 265-268. [CrossRef]

29. Shibata, M.; Ohkubo, T.; Takahashi, H.; Inoki, R. Modified formalin test: Characteristic biphasic pain response. Pain 1989, 38, 347-352. [CrossRef]

30. Ghannadi, A.; Hajhashem, V.; Jafarabadi, H. An investigation of the analgesic and anti-inflammatory effects of Nigella sativa seed polyphenols. J. Med. Food 2005, 8, 488-493. [CrossRef] [PubMed]

31. Rititid, W.; Ruangsang, P.; Reanmongkol, W.; Wongnawa, M. Studies of the anti-inflammatory and antipyretic activities of the methanolicextract of Piper sarmentosumRoxb.Leaves in rats. Songklanakarin J. Sci. Technol. 2007, 6, 1519-1526.

32. Ayoub, S.S.; Colville, N.P.R.; Willoughby, D.A.; Botting, R.M. The involvement of a cyclooxygenase-1 gene-derived protein in the antinociceptive action of paracetamol in mice. Eur. J. Pharmacol. 2006, 538, 57-65. [CrossRef] [PubMed]

33. Chandrasekharan, D.V.; Roos, H.; Evanson, K.I.; Tomsik, N.K.; Elton, J.; Simmons, T. Cox-3, a cox-1 variant inhibited by acetaminophen and other analgesic/antipyretic drugs: Cloning, structure and expression. Proc. Natl. Acad. Sci. USA 2002, 139, 26-31. [CrossRef] [PubMed] 
34. Kadam, R.U.; Roy, N. Recent trends in drug-likeness prediction: A comprehensive Review of in silicomethods. Indian J. Pharm. Sci. 2007, 69, 609-615.

35. Ghose, A.K.; Herbertz, T.; Hudkins, R.L.; Dorsey, B.D.; Mallamo, J.P. Knowledge-based, central nervous system (CNS) lead selection and lead optimization for CNS drug discovery. ACS Chem. Neurosci. 2012, 3, 50-68. [CrossRef] [PubMed]

36. Bakht, M.A.; Yar, M.S.; Abdel-Hamid, S.G.; Al Qasoumi, S.I.; Samad, A. Molecular properties prediction, synthesis and antimicrobial activity of some newer oxadiazole derivatives. Eur. J. Med. Chem. 2010, 45, 5862-5869. [CrossRef] [PubMed]

37. Tian, S.; Wang, J.; Li, Y.; Li, D.; Xu, L.; Hou, T. The application of in silico drug-likeness predictions in pharmaceutical research. Adv. Drug Deliv. Rev. 2015, 86, 2-10. [CrossRef] [PubMed]

38. Jadhav, P.B.; Yadav, A.R.; Gore, M.G. Concept of drug likeness in pharmaceutical research. Int. J. Pharm. Biol. Sci. 2015, 6, 142-154.

39. Amaravani, M.; Prasad, N.K.; Ramakrishna, V. COX-2 structural analysis and docking studies with gallic acid structural analogues. SpringerPlus 2012, 1, 58. [CrossRef] [PubMed]

40. Elengoe, A.; Naser, M.A.; Hamdan, S. Modeling and docking studies on novel mutants (K71L and T204V) of the ATPase domain of human heat shock 70kDa protein 1. Int. J. Mol. Sci. 2014, 15, 6797-6814. [CrossRef] [PubMed]

41. Kufareva, I.; Abagyan, R. Methods of protein structure comparison. Methods Mol. Biol. 2012, 857, $231-257$. [PubMed]

42. Nwafor, P.A.; Okwuasaba, F.K. Antinociceptive and anti-inflammatory effects of methanolic extract of Asparagus pubescans roots in rodents. J. Ethanopharmacol. 2003, 84, 125-129. [CrossRef]

43. Akah, P.A.; Nwambie, A.L. Evaluation of Nigerian traditional medicines: Plants used for rheumatic disorders. J. Ethanopharmacol. 1994, 42, 179-182. [CrossRef]

44. Koster, R.; Anderson, M.; Debeer, J.M. Acetic acid used for analgesic screening. Fed. Proc. 1959, 18, 412-416.

45. Correa, C.R.; Calixto, J.B. Evidence of participation of $\beta 1$ and $\beta 2$ Kinin receptors in formation-induced nociceptive response in mouse. Br. J. Pharmacol. 1993, 110, 193-198. [CrossRef] [PubMed]

46. Sakande, J.; Nacoulma, O.G.; Nikiema, J.B.; Lompo, M.; Bassene, E.; Guissou, I.P. Etude de1'effet antipyretique d'extraits des inflorescences malesduronier Borassusaethiopum Mart (Arecaceae). Med. Afr. N. 2004, 51, 280-282.

47. Ezer, E.; Palosi, E.; Hajos, G.; Szporny, L. Antagonism of the gastrointestinal ulcerogenic effect of some nonsteroidal anti-inflammatory agents by sodium salicylate. J. Pharm. Pharmacol. 1976, 28, 655-656. [CrossRef] [PubMed]

48. Vogel, W.H. Analgesic, anti-inflammatory, and antipyretic activity. In Drug Discovery and Evaluation; Springer: Berlin/Heidelberg, Germany, 1997; pp. 360-420.

49. Majumdar, B.; Chaudhari, S.G.R.; Ray, A.; Bandyopadhyay, S.K. Effect of ethanol extract of Piper betle Linn leaf on healing of NSAID-induced experimental ulcer-a novel role of free radical scavenging action. Indian J. Exp. Biol. 2003, 41, 311-315. [PubMed]

50. Kimura, Y.; Tani, T.; Kanbe, T.; Watanabe, K. Effect of cilostazol on platelet aggregation and experimental thrombosis. Drug Res. 1985, 35, 1144-1149.

51. Lovell, S.C.; Davis, I.W.; Arendall, W.B., 3rd; de Bakker, P.I.; Word, J.M.; Prisant, M.G.; Richardson, J.S.; Richardson, D.C. Structure validation by C $\alpha$ geometry: Phi,psi and C $\beta$ deviation. Proteins 2003, 50, 437-450. [CrossRef] [PubMed]

52. Chen, V.B.; Arendall, W.B., 3rd; Headd, J.J.; Keedy, D.A.; Immormino, R.M.; Kapral, G.J.; Murray, L.W.; Richardson, J.S.; Richardson, D.C. MolProbity: All-atom structure validation for macromolecular crystallography. Acta Crystallogr. D Biol. Crystallogr. 2010, 66, 12-21. [CrossRef] [PubMed]

53. Pettersen, E.F.; Goddard, T.D.; Huang, C.C.; Couch, G.S.; Greenblatt, D.M.; Meng, E.C.; Ferrin, T.E. UCSF Chimera-A visualization system for exploratory research and analysis. J. Comput. Chem. 2004, 25, 1605-1612. [CrossRef] [PubMed]

54. Dallakyan, S.; Olson, A.J. Small-molecule library screening by docking with PyRx. Methods Mol. Biol. 2015, 1263, 243-250. [PubMed]

55. Studio. Discovery, version 2.1; Accelrys: San Diego, CA, USA, 2008. 
56. Pronk, S.; Páll, S.; Schulz, R.; Larsson, P.; Bjelkmar, P.; Apostolov, R.; Shirts, M.R.; Smith, J.C.; Kasson, P.M.; van der Spoel, D.; et al. GROMACS 4.5: A high-throughput and highly parallel open source molecular simulation toolkit. Bioinformatics 2013, 29, 845-854. [CrossRef] [PubMed]

57. Oostenbrink, C.; Villa, A.; Mark, A.E.; van Gunsteren, W.F. Abiomolecular force field based on the free enthalpy of hydration and solvation: The GROMOS force-field parameter sets 53A5 and 53A6. J. Comput. Chem. 2004, 25, 1656-1676. [CrossRef] [PubMed]

58. Schüttelkopf, A.W.; van Aalten, D.M. PRODRG: A tool for high-throughput crystallography of protein-ligand complexes. Acta Crystallogr. D Biol. Crystallogr. 2004, 60, 1355-1363. [CrossRef] [PubMed]

59. Wang, H.; Dommert, F.; Holm, C. Optimizing working parameters of the smooth particle mesh Ewald algorithm in terms of accuracy and efficiency. J. Chem. Phys. 2010, 133, 034117. [CrossRef] [PubMed]

60. Amiri, S.; Sansom, M.S.; Biggin, P.C. Molecular dynamics studies of AChBP with nicotine and carbamylcholine: The role of water in the binding pocket. Protein Eng. Des. Sel. 2007, 20, 353-359. [CrossRef] [PubMed]

61. Labik, S.; Smith, W.R. Scaled Particle Theory and the Efficient Calculation of the Chemical-Potential of Hard-Spheres in the Nvt Ensemble. Mol. Simul. 1994, 12, 23-31. [CrossRef]

(C) 2016 by the authors; licensee MDPI, Basel, Switzerland. This article is an open access article distributed under the terms and conditions of the Creative Commons Attribution (CC-BY) license (http://creativecommons.org/licenses/by/4.0/). 